\title{
SOME REMARKS ON GLASS SEALS FROM THE TERRITORY OF POLAND FROM THE $17^{\mathrm{TH}}-19^{\mathrm{TH}}$ CENTURIES
}

\begin{abstract}
This paper presents information about modern glass seals obtained during archaeological excavations carried out on the territory of modern-day Poland after 1987. The author reviews finds and their characteristics and based on such collected data attempts to indicate their quantitative diversity, territorial range, and chronology. The paper also focuses on markings identified on glass seals divided by their types. These are individualised signs, monograms, symbols, descriptive signs, and numerical signs, mostly trademarks. This analysis aims to outline the state of research and indicate various research questions associated with the production and use of stamped glass vessels in Poland, which require further studies.
\end{abstract}

Keywords: glass seals, glass bottles, bottles with seals, glass finds, Poland, $17^{\text {th }}-19^{\text {th }}$ century

Received: 20.08.2020 Revised: 12.09 .2020 Accepted: 08.10.2020

Citation: Bis M. 2020. Some Remarks on Glass Seals from the Territory of Poland from the $17^{\text {th }}-19^{\text {th }}$ Centuries. "Fasciculi Archaeologiae Historicae" 33, 133-157, DOI 10.23858/FAH33.2020.009

\section{Introduction}

Glass bottles with stamps (seals) made of the same material ${ }^{1}$ and glass seals attached to parts of bodies of glass vessels, are one of the most interesting archaeological artefacts. They stand out among the mass finds classified as glass cullet obtained during excavations on sites dated to the modern period, particularly in the large volume of a rather uniform bottle glass, since they are artefacts recorded usually in small numbers. The seals themselves, although small and often of a rather modest appearance, are characterised by considerable stylistic diversity, and in light of Polish publications released to date, similar specimens are usually registered on a rather

*Institute of Archaeology and Ethnology, Polish Academy of Sciences, Warsaw; (D http://orcid.org/0000-0002-0108-7625; magdabis@wp.pl; magdabis@iaepan.edu.pl

${ }^{1}$ In Polish archaeological literature, both terms are commonly used. In this paper, I also use them interchangeably. However, both expressions are ambiguous and imprecise in relation to the analysed artefacts (this problem was already signalled by Andrzej Gołębiewski - Gołębiewski 1997, 184, footnote 1). In terms of the semantics (as an ownership and identification marking) and the manufacturing technique, it would be more appropriate to use the term seal. limited territory. Furthermore, inscriptions and pictograms placed on the seals may have different meanings or are difficult to explain and remain a mystery. However, the artistic qualities of the seals are of secondary importance, being subordinated to their primary function - utilitarian, as stamps were predominantly carriers of information about production and commerce, regarding workshops, manufacturers, and purchasers of these products, potential outlets, the capacity of the vessels and the amount of liquid stored in them. Markings on bottles also conformed to officially imposed requirements or advertised the goods labelled with them (both the vessel and its contents). Such products were used for storing, transporting, and serving mostly alcoholic beverages, mainly wine, beer, vodka, gin, and spirits, as well as mineral water.

The use of such markings on modern glass vessels from the territory of Poland may be seen as the consequence of the relationships and economic and cultural influences between various countries on the European continent at that time. This was the result of reproducing practices already tested and widespread abroad, which were also applied to local glass manufacturing and gained a good reputation among the local consumers. 
This was also the consequence of general tendencies towards the standardisation of glass packaging and the implementation of the imposed fiscal restrictions.

The custom of labelling glass containers in the form of stamps impressed in glass has western origins dating to around the mid- $17^{\text {th }}$ century. It subsequently became widespread and was used across the continent as well as in North America. It was most commonly used in the $18^{\text {th }}$ century and in the first half of the $19^{\text {th }}$ century. ${ }^{2}$

Such finds also spark interest among Polish archaeologists, leading to papers and monographs dedicated to the problem of stamped glass bottles and glass vessels. Based on the review of the Polish literature published since 1987, we can see a gradual increase in the number of such studies, particularly during the last few years. ${ }^{3}$ Despite the fact that the discussion on this type of artefacts was already included in many publications, this research problem is still far from being investigated thoroughly.

In this paper, I tried to collate the most important information about the above-mentioned finds published since that time, in order to bring them closer to readers and characterise them, as well as summarise the associated research problems and the current state of research at a national level. This discussion is of a preliminary nature. Its objective is to present the multitude and diversity of issues related to this type of artefacts, including outlining potential directions of further studies on the production, use, and distribution of glass vessels with seals in the territory of modern Poland.

\section{A review of Polish finds of glass seals and main research findings}

In Polish archaeological literature, such artefacts were recorded among other finds already as early as in the $1970 \mathrm{~s},{ }^{4}$ although it was Leszek Kajzer who first paid more attention to them in his paper on the import of beer from the British Isles and glass containers used for that purpose, including bottles of English provenance. ${ }^{5}$ The breakthrough came with a paper written by Andrzej Gołębiewski, which was published several

${ }^{2}$ More information on this subject e.g. in Morgan 1976, 7-23; Polak 1981, 234-239, 261-264; Dumbrell 1983, 13-23; van den Bossche 2001; Veit and Huey 2014, 56-60; Jeffries and Major $2015,132-133$. Since there are numerous publications on this subject, I list here only several selected works. Research questions concerning the history of using glass bottles with seals have also been discussed many times in Polish archaeological publications. For this reason, in this paper, I decided to include only a short reference.

${ }^{3}$ See Bis 2020a.

${ }^{4}$ E.g. Cnotliwy et al. 1972, 216; Gajewska and Kruppé 1973, 629 , footnote 20 .

${ }^{5}$ Kajzer 1981. years later. ${ }^{6}$ It contained fundamental findings, which are still valid, concerning the formal analysis of glass seals, their classification, and comprehensive interpretation. From our current perspective, we may state, together with the progress of studies on this type of finds in other European countries, ${ }^{7}$ that both works became the impulse for other scholars to take up this research problem and set out a number of future research trends.

The result of the above-mentioned inspirations was the creation and publication in Poland during the last two decades of eight papers dedicated exclusively to glass seals and bottles. ${ }^{8}$ Those artefacts have also become a subject of a wider discussion in connection with descriptions of collections of glass artefacts that included such finds discovered in different parts of modern-day Poland. ${ }^{9}$ As a result, the subject of glass seals has been discussed relatively often in the context of publications on other types of modern glass vessels. ${ }^{10}$ However, researchers have concentrated mainly on the set of information discussing: the state of preservation and the appearance of finds, in particular of the symbols impressed on seals, their function and origin, and enumerating other sites with such finds. Among more recent publications, only a few authors have adopted a more comprehensive approach to studies on artefacts with glass seals. ${ }^{11}$

To gain an approximate, comprehensive image concerning the current state of glass seals finds from the territory of contemporary Poland recorded after the year 1987 basic data are compiled in Table 1. That set of information includes selected artefacts, i.e. varying in terms of the location and the category of sites on which they were discovered, and simultaneously recorded in publications that made it possible to establish in the relevant assemblages of finds the proportion between artefacts with glass seals and other the remaining glass finds without any stamps or markings. ${ }^{12}$

\footnotetext{
${ }^{6}$ Gołębiewski 1997.

${ }^{7}$ This phenomenon is manifested through, among other things, several key works published et the end of the $20^{\text {th }}$ century and the beginning of the $21^{\text {st }}$ century, including: Friese and Friese 1992; van den Bossche 2001; Humbsch 2001; Humbsch 2002.

${ }^{8}$ Woźny 2001; Siwiak 2003; Siwiak 2004; Krukowska 2007a; Siwiak 2007a; Siwiak 2007b; Siwiak 2009; Szczepanowska 2013.

${ }^{9}$ E.g. Nawracki 1999, 91-93; Krukowska 2007b, 35-46; Antowska-Gorączniak 2012, 151, 194, Pl. 6; Rais-Kufel and Kufel 2013, 237-278; Wojciechowska 2015; Grabny 2016, 261-263; Wilgocka 2016, 227-228, 238-239, Figs. 5 and 6; Baturo 2017, 217-223, 235, P1. 5; Baturo and Kasprzak 2018a; Baturo and Kasprzak 2018b.

${ }^{10}$ See Bis 2020a.

${ }^{11}$ Woźny 2001; Siwiak 2003; Siwiak 2007a; Szczepanowska 2013; Baturo 2017.

${ }^{12} \mathrm{I}$ have taken into consideration those publications, which in addition to the number of glass seals provided information about the total number of discovered bottles and their fragments or the total number of glass vessels.
} 
Table 1. Selected examples of glass seals (loose and with glass vessels) dated to the $17^{\text {th }}-19^{\text {th }}$ centuries from the territory of Poland (compiled by M. Bis, based on data contained in publications)

\begin{tabular}{|c|c|c|c|c|c|c|}
\hline No. & $\begin{array}{c}\text { Place } \\
\text { of discovery }\end{array}$ & $\begin{array}{l}\text { Number } \\
\text { of glass vessels / } \\
\text { Number of } \\
\text { bottles }\end{array}$ & $\begin{array}{c}\text { Number } \\
\text { of seals, glass } \\
\text { bottles or their } \\
\text { fragments with } \\
\text { seals }\end{array}$ & $\begin{array}{l}\text { Types of signs } \\
\text { on seals }\end{array}$ & Dating & Publication \\
\hline 1 & $\begin{array}{l}\text { Bąkowa Góra, } \\
\text { manor house, } \\
\text { Łódzkie } \\
\text { Voivodeship }\end{array}$ & $\begin{array}{l}875 \text { fragments } \\
\text { of glass } \\
\text { vessels / } \\
\text { no data }\end{array}$ & $8 *$ seals & $\begin{array}{l}\text { descriptive signs - with } \\
\text { trademarks }(\mathrm{FJL}, \mathrm{TK}) \text {; } \\
\text { numerical }(\mathrm{G} 1, \mathrm{G} 1 / 2,1 \mathrm{KW}) \text {; } \\
3 \text { without a stamp }\end{array}$ & $18^{\text {th }}$ century & Głosek 1998 \\
\hline 2 & $\begin{array}{l}\text { Białystok, palace } \\
\text { (Pałacyk Gościnny, } \\
2 \text { Kilińskiego Street, } \\
\text { site 2), Podlaskie } \\
\text { Voivodeship }\end{array}$ & $\begin{array}{l}\text { no data / } \\
309 \text { bottle* } \\
\text { fragments } \\
\text { (including: } \\
2 \text { squat bottles) }\end{array}$ & $\begin{array}{l}1 \text { specimen } \\
\text { (a piece of } \\
\text { a squat bottle } \\
\text { with a seal) }\end{array}$ & $\begin{array}{l}\text { a descriptive sign - with } \\
\text { a town (?) name, partly } \\
\text { preserved (Do }[\ldots] \text { to }[\ldots] \text { ?) }\end{array}$ & $\begin{array}{l}2^{\text {nd }} \text { half of the } \\
18^{\text {th }} \text { century }\end{array}$ & Pawlata 2010 \\
\hline 3 & $\begin{array}{l}\text { Brześć Kujawski, } \\
\text { priory } \\
\text { (Dominicans), } \\
\text { Kujawsko-Pomorskie } \\
\text { Voivodeship }\end{array}$ & $\begin{array}{l}257 \text { fragments } \\
\text { of glass } \\
\text { vessels / } \\
45 \text { bottles }\end{array}$ & $\begin{array}{l}3 \text { bottles } \\
\text { with seals }\end{array}$ & $\begin{array}{l}\text { a descriptive sign - with the } \\
\text { name of the glass workshop } \\
\text { (Art. Huta Zo[...]); numerical } \\
\text { signs (K1, K2) }\end{array}$ & $\begin{array}{l}2^{\text {nd }} \text { half of the } \\
18^{\text {th }} \text { century- } \\
1820 \text { s- } 1830 \text { s }\end{array}$ & $\begin{array}{l}\text { Andrzejewska } \\
1996\end{array}$ \\
\hline 4 & $\begin{array}{l}\text { Bydgoszcz, town } \\
\text { (plot located at } \\
33 \text { Pod Blankami } \\
\text { Street, site 556), } \\
\text { Kujawsko- } \\
\text { Pomorskie } \\
\text { Voivodeship }\end{array}$ & $\begin{array}{l}\text { no data / } \\
121 \text { bottle } \\
\text { fragments } \\
\text { (storage } \\
\text { containers and } \\
\text { pharmaceutical } \\
\text { glass) }\end{array}$ & 5 seals & $\begin{array}{l}\text { a descriptive sign - with } \\
\text { the name of the glass work- } \\
\text { shop (Glas Fab [T]hu[re]), } \\
\text { symbols (star, eagle), } \\
\text { monogram }(\mathrm{K})\end{array}$ & $\begin{array}{l}2^{\text {nd }} \text { half of the } \\
18^{\text {th }} \text { century } \\
-2^{\text {nd }} \text { and } 3^{\text {th }} \\
\text { quarter of the } \\
19^{\text {th }} \text { century }\end{array}$ & Siwiak 2002 \\
\hline 5 & $\begin{array}{l}\text { Bydgoszcz, town } \\
\text { (Przedmieście } \\
\text { Gdańskie, site 533), } \\
\text { Kujawsko- } \\
\text { Pomorskie } \\
\text { Voivodeship }\end{array}$ & $\begin{array}{l}\text { no data / } \\
28 \text { bottle } \\
\text { fragments }\end{array}$ & 18 seals & $\begin{array}{l}\text { descriptive signs - with the } \\
\text { name of the glass workshop } \\
\text { (Glas Fabrik Clementienhof), } \\
\text { the glass workshop and town } \\
\text { (Baeren Walde) }\end{array}$ & $\begin{array}{l}\text { turn of the } \\
18^{\text {th }} \text { century }\end{array}$ & Siwiak 2009 \\
\hline 6 & $\begin{array}{l}\text { Chojnice, school } \\
\text { (Jesuit College), } \\
\text { Pomorskie } \\
\text { Voivodeship }\end{array}$ & $\begin{array}{l}990 \text { fragments } \\
\text { of glass vessels } \\
\text { / } 741 \text { bottle } \\
\text { fragments }\end{array}$ & 8 seals & $\begin{array}{l}\text { descriptive signs - with the } \\
\text { name of the town (London, } \\
\text { Londn, Londen) }\end{array}$ & $\begin{array}{l}18^{\text {th }}-19^{\text {th }} \\
\text { century }\end{array}$ & $\begin{array}{l}\text { Garas and } \\
\text { Trzciński } \\
2010\end{array}$ \\
\hline 7 & $\begin{array}{l}\text { Dubno, } \\
\text { manor house, } \\
\text { Podlaskie } \\
\text { Voivodeship }\end{array}$ & $\begin{array}{l}1627 \text { fragments } \\
\text { of glass vessels } \\
\text { / no data }\end{array}$ & 2 seals & $\begin{array}{l}\text { descriptive signs - with the } \\
\text { name of the town (London) } \\
\text { and undentified, partly pre- } \\
\text { served (Crus }[\ldots] \text { Hirs }[\ldots] \text { Bo) }\end{array}$ & $18^{\text {th }}$ century & $\begin{array}{l}\text { Garas and } \\
\text { Karwowska } \\
2013\end{array}$ \\
\hline 8 & $\begin{array}{l}\text { Elbląg, town } \\
\text { (Old Town), } \\
\text { Warmińsko- } \\
\text { Mazurskie } \\
\text { Voivodeship }\end{array}$ & $\begin{array}{l}\text { no data / many } \\
\text { thousands of } \\
\text { bottle fragments }\end{array}$ & $\begin{array}{l}37 \text { bottles } \\
\text { with seals } \\
\text { (and } 11 \text { frag- } \\
\text { ments of necks } \\
\text { with stamped } \\
\text { reference } \\
\text { numbers) }\end{array}$ & $\begin{array}{l}\text { descriptive signs - with place } \\
\text { names (including London in } \\
\text { different spelling options); } \\
\text { trademarks (FR), numerical } \\
\text { (e.g. } 1 / 2 \mathrm{Q}, 1 / 26, \mathrm{~N}^{\circ} \text { ), } \\
\text { symbols (crown?, a bunch of } \\
\text { grapes), } 8 \text { seals without any } \\
\text { imprints. }\end{array}$ & $\begin{array}{l}\text { end of the } \\
17^{\text {th }}-18^{\text {th }} \\
\text { century; } \\
19^{\text {th }} \text { century }\end{array}$ & $\begin{array}{l}\text { Gołębiewski } \\
1997\end{array}$ \\
\hline
\end{tabular}




\begin{tabular}{|c|c|c|c|c|c|c|}
\hline No. & $\begin{array}{c}\text { Place } \\
\text { of discovery }\end{array}$ & $\begin{array}{l}\text { Number } \\
\text { of glass vessels / } \\
\text { Number of } \\
\text { bottles }\end{array}$ & $\begin{array}{c}\text { Number } \\
\text { of seals, glass } \\
\text { bottles or their } \\
\text { fragments with } \\
\text { seals }\end{array}$ & $\begin{array}{l}\text { Types of signs } \\
\text { on seals }\end{array}$ & Dating & Publication \\
\hline 9 & $\begin{array}{l}\text { Gdańsk, town } \\
\text { (Market Hall, } \\
\text { site 5), Pomorskie } \\
\text { Voivodeship }\end{array}$ & $\begin{array}{l}313 \text { fragments } \\
\text { of glass vessels / } \\
205 \text { bottle frag- } \\
\text { ments (including: } \\
94 \text { from square } \\
\text { bottles, } 108 \text { from } \\
\text { cylindrical, } 3 \\
\text { from demijohns) }\end{array}$ & $\begin{array}{l}1 \text { specimen } \\
\text { (a piece of } \\
\text { a rectangular } \\
\text { bottle with } \\
\text { a seal) }\end{array}$ & $\begin{array}{l}\text { descriptive signs - with the } \\
\text { name of the town (Londo) }\end{array}$ & $\begin{array}{l}\text { end of the } 17^{\text {th }} \\
-18^{\text {th }} \text { century }\end{array}$ & $\begin{array}{l}\text { Krukowska } \\
2007 b\end{array}$ \\
\hline 10 & $\begin{array}{l}\text { Gdańsk, town } \\
\text { (Szafarnia-Angielska } \\
\text { Grobla, site 100), } \\
\text { Pomorskie } \\
\text { Voivodeship }\end{array}$ & $\begin{array}{l}3940 \text { fragments } \\
\text { of glass } \\
\text { artefacts / } \\
2405 \text { fragments } \\
\text { of bottles and } \\
\text { demijohns }\end{array}$ & $\begin{array}{l}8 \text { specimens } \\
\text { (including: } \\
5 \text { bottles with } \\
\text { seals and three } \\
\text { loose seals) }\end{array}$ & $\begin{array}{l}\text { descriptive signs - with the } \\
\text { name of the town (London, } \\
\text { Londo, Dantzig); } 1 \text { seal } \\
\text { without a sign }\end{array}$ & $\begin{array}{l}\text { end of the } 17^{\text {th }} \\
-18^{\text {th }} \text { century }\end{array}$ & $\begin{array}{l}\text { Szczepanow- } \\
\text { ska } 2013\end{array}$ \\
\hline 11 & $\begin{array}{l}\text { Łowicz, town } \\
\text { (New Town } \\
\text { Hall), Łódzkie } \\
\text { Voivodeship }\end{array}$ & $\begin{array}{l}1309 \text { fragments } \\
\text { of glass } \\
\text { vessels / } \\
240 \text { bottle } \\
\text { fragments }\end{array}$ & $\begin{array}{l}6 \text { fragments } \\
\text { of bottles } \\
\text { with seals }\end{array}$ & $\begin{array}{l}\text { a descriptive sign - with the } \\
\text { name of the glass workshop } \\
\text { (Huta Olichawska, Huta Oli- } \\
\text { chawsky), monograms (S.F, } \\
\text { H.R), numerical (K2), sym- } \\
\text { bols (crown?), } 1 \text { illegible sign }\end{array}$ & $\begin{array}{l}\text { c. } 2^{\text {nd }} \text { half of } \\
\text { the } 17^{\text {th }} \text { - begin- } \\
\text { ning of the } \\
19^{\text {th }} \text { century }\end{array}$ & $\begin{array}{l}\text { Poturalska } \\
1999\end{array}$ \\
\hline 12 & $\begin{array}{l}\text { Pomorzanki, } \\
\text { village, } \\
\text { Łódzkie } \\
\text { Voivodeship }\end{array}$ & $\begin{array}{l}504 \text { fragments } \\
\text { of glass vessels } \\
\text { / } 262 \text { bottle } \\
\text { fragments }\end{array}$ & 1 seal & $\begin{array}{l}\text { trademark (?) - name of the } \\
\text { manufacturer or the consumer } \\
\text { (?), partly preserved (Zskow) }\end{array}$ & $\begin{array}{l}18^{\text {th }} \text {-beginning } \\
\text { of the } 19^{\text {th }} \\
\text { century (?) }\end{array}$ & Słomska 2013 \\
\hline 13 & $\begin{array}{l}\text { Poznań, town } \\
\text { (Stawna/Żydowska } \\
\text { Street), Wielkopolskie } \\
\text { Voivodeship }\end{array}$ & $\begin{array}{l}203 \text { fragments } \\
\text { of glass vessels } \\
\text { / } 172 \text { bottle } \\
\text { fragments }\end{array}$ & 5 seals & $\begin{array}{l}\text { descriptive signs - with the } \\
\text { name of the town (Ondo, } \\
\text { Onde), trademarks (Ha [...] } \\
\text { Glais; Hartwig), symbols } \\
\text { (the Star of David, fish) }\end{array}$ & $\begin{array}{l}2^{\text {nd }} \text { half } \\
\text { of the } 18^{\text {th }}-20^{\text {th }} \\
\text { century }\end{array}$ & Kufel 2018 \\
\hline 14 & $\begin{array}{l}\text { Puck, town } \\
\text { (town hall) } \\
\text { Pomorskie } \\
\text { Voivodeship }\end{array}$ & $\begin{array}{l}2644 \text { fragments } \\
\text { of glass ves- } \\
\text { sels / } 72 \text { bottle } \\
\text { fragments and } \\
4 \text { whole bottles } \\
\text { (reconstructed) }\end{array}$ & 3 seals & $\begin{array}{l}\text { descriptive signs - with the } \\
\text { name of the town (London, } \\
\text { Lipusch), miscellaneous } \\
\text { sign (Secken) }\end{array}$ & $\begin{array}{l}4^{\text {th }} \text { quarter of } \\
\text { the } 18^{\text {th }}-1^{\text {st }} \text { half } \\
\text { of the } \\
19^{\text {th }} \text { century }\end{array}$ & Starski 2015 \\
\hline 15 & $\begin{array}{l}\text { Sandomierz, town } \\
\text { (Collegium } \\
\text { Gostomianum), } \\
\text { Świętokrzyskie } \\
\text { Voivodeship }\end{array}$ & $\begin{array}{l}540 \text { fragments } \\
\text { of glass vessels } \\
\text { / } 204 \text { bottles }\end{array}$ & 1 seal & $\begin{array}{l}\text { a descriptive sign or } \\
\text { a trademark (HP) }\end{array}$ & $\begin{array}{l}17^{\text {th }}-18^{\text {th }} \\
\text { century }\end{array}$ & $\begin{array}{l}\text { Rubnikowicz } \\
\text { 1996, 447, } \\
\text { Tab. V:14 }\end{array}$ \\
\hline 16 & $\begin{array}{l}\text { Siedlęcin, tower } \\
\text { castle, Dolnośląskie } \\
\text { Voivodeship }\end{array}$ & $\begin{array}{l}2539 \text { fragments } \\
\text { of glass vessels } \\
\text { / } 29 \text { storage } \\
\text { bottles* }\end{array}$ & 3 seals & $\begin{array}{l}\text { a descriptive sign - with the } \\
\text { name of the town and glass } \\
\text { workshop (Kolzig; [C]rlstahl); } \\
\text { numerical sign (K 7/4 Q) }\end{array}$ & $\begin{array}{l}\text { year } 1765 ; \\
\text { from } 1754 \\
\text { to the } 1890 \mathrm{~s}\end{array}$ & Grabny 2016 \\
\hline 17 & $\begin{array}{l}\text { Stargard, town } \\
\text { (quarter V), } \\
\text { Zachodniopomorskie } \\
\text { Voivodeship }\end{array}$ & $\begin{array}{l}186 \text { fragments } \\
\text { of glass vessels } \\
\text { / } 158 \text { bottle } \\
\text { fragments }\end{array}$ & 3 seals & $\begin{array}{l}\text { descriptive signs - with the } \\
\text { name of the town and glass } \\
\text { workshop (Marienwalde 1739; } \\
\text { M. L / Bernsee / Glasshot[t]e); } \\
\text { a trademark (?) (ICK) }\end{array}$ & $\begin{array}{l}\text { end of the } \\
17^{\text {th }} \text {-mid- } 19^{\text {th }} \\
\text { century }\end{array}$ & $\begin{array}{l}\text { Majewski } \\
2012\end{array}$ \\
\hline
\end{tabular}




\begin{tabular}{|c|c|c|c|c|c|c|}
\hline No. & $\begin{array}{c}\text { Place } \\
\text { of discovery }\end{array}$ & $\begin{array}{l}\text { Number } \\
\text { of glass vessels / } \\
\text { Number of } \\
\text { bottles }\end{array}$ & $\begin{array}{c}\text { Number } \\
\text { of seals, glass } \\
\text { bottles or their } \\
\text { fragments with } \\
\text { seals }\end{array}$ & $\begin{array}{l}\text { Types of signs } \\
\text { on seals }\end{array}$ & Dating & Publication \\
\hline 18 & $\begin{array}{l}\text { Stargard, church } \\
\text { (of the Augustinians), } \\
\text { Zachodniopomorskie } \\
\text { Voivodeship }\end{array}$ & $\begin{array}{l}\text { no data / } \\
2589 \text { bottle } \\
\text { fragments* }\end{array}$ & $\begin{array}{l}33 \text { (?) seals } \\
\text { (including: } \\
28 \text { identified } \\
\text { loose finds } \\
\text { and } 5 \text { (?) } \\
\text { unidentified }\end{array}$ & $\begin{array}{l}\text { descriptive signs - with the } \\
\text { name of the town and glass } \\
\text { workshop (e.g. Piep Stock, } \\
\text { Marienwalde, Cantreck), } \\
\text { a trademark (Bergemann } \\
\text { Erben), with unclear words } \\
\text { (Minch), numerical (No 3; 1) }\end{array}$ & $\begin{array}{l}17^{\text {th }}-19^{\text {th }} \\
\text { century }\end{array}$ & $\begin{array}{l}\text { Wilgocka } \\
2016\end{array}$ \\
\hline 19 & $\begin{array}{l}\text { Średnia Huta, } \\
\text { glass workshop, } \\
\text { Kujawsko- } \\
\text { Pomorskie } \\
\text { Voivodeship }\end{array}$ & $\begin{array}{l}1083 \text { fragments } \\
\text { of glass vessels* } \\
\text { / } 241 \text { bottle } \\
\text { fragments }\end{array}$ & 3 seals & $\begin{array}{l}\text { descriptive signs - with the } \\
\text { name of the town (Londo) }\end{array}$ & $18^{\text {th }}$ century & $\begin{array}{l}\text { Rubnikowicz } \\
\text { 1989a }\end{array}$ \\
\hline 20 & $\begin{array}{l}\text { Szczecin, castle } \\
\text { (Castle of the Dukes } \\
\text { of Pomerania), } \\
\text { Zachodniopomorskie } \\
\text { Voivodeship }\end{array}$ & $\begin{array}{l}\text { no data / } \\
68 \text { bottle } \\
\text { fragments* }\end{array}$ & 9 seals & $\begin{array}{l}\text { descriptive signs - with the } \\
\text { name of the town and glass } \\
\text { workshop (Annenwalde, } \\
\text { Marienwalde) }\end{array}$ & $\begin{array}{l}18^{\text {th }}-19^{\text {th }} \text { centu- } \\
\text { ry (after } 1637 \text { ) }\end{array}$ & $\begin{array}{l}\text { Cnotliwy } \\
2014\end{array}$ \\
\hline 21 & $\begin{array}{l}\text { Toruń, castle, } \\
\text { Kujawsko- } \\
\text { Pomorskie } \\
\text { Voivodeship }\end{array}$ & $\begin{array}{l}226 \text { fragments } \\
\text { of glass } \\
\text { vessels / } \\
61 \text { bottle } \\
\text { fragments }\end{array}$ & 7 seals & $\begin{array}{l}\text { descriptive signs - with place } \\
\text { names (London), with } \\
\text { a monogram (R), with } \\
\text { an unclear sign (KWD/Y); } \\
2 \text { without a stamp }\end{array}$ & $18^{\text {th }}$ century & $\begin{array}{l}\text { Nawracki } \\
1999\end{array}$ \\
\hline 22 & $\begin{array}{l}\text { Warsaw, town } \\
\text { (Plac Zamkowy), } \\
\text { Mazowieckie } \\
\text { Voivodeship }\end{array}$ & $\begin{array}{l}\text { no data / over } \\
17,000 \text { bottle } \\
\text { fragments }\end{array}$ & $\begin{array}{l}59 \text { seals } \\
\text { (including: } \\
4 \text { on whole } \\
\text { bottles and } \\
15 \text { on bottles } \\
\text { preserved in } \\
\text { fragments) }\end{array}$ & $\begin{array}{l}\text { descriptive signs - with } \\
\text { names of glass workshops } \\
\text { (e.g. Piekarska, Stanislawo- } \\
\text { wa, Jezewicka, Blendow, } \\
\text { Lochow); with unclear ini- } \\
\text { tials (e.g. HP; WD HW; FK); } \\
\text { numerical signs - identifying } \\
\text { measures ( } 3 \text { Quart, KIII); } \\
7 \text { without a stamp }\end{array}$ & $\begin{array}{l}2^{\text {nd }} \text { half } \\
\text { of the } \\
18^{\text {th }}-19^{\text {th }} \\
\text { century }\end{array}$ & Baturo 2017 \\
\hline 23 & $\begin{array}{l}\text { Warsaw, town } \\
\text { (town hall), } \\
\text { Mazowieckie } \\
\text { Voivodeship }\end{array}$ & $\begin{array}{l}948 \text { glass ves- } \\
\text { sels / no data }\end{array}$ & 2 seals & $\begin{array}{l}\text { descriptive signs - with the } \\
\text { name of the town (Dantzig, } \\
\text { Londen) }\end{array}$ & $\begin{array}{l}4^{\text {th }} \text { quarter of } \\
\text { the } 18^{\text {th }}-1^{\text {st }} \\
\text { quarter of the } \\
19^{\text {th }} \text { century }\end{array}$ & $\begin{array}{l}\text { Blusiewicz } \\
2013\end{array}$ \\
\hline 24 & $\begin{array}{l}\text { Wrocław, town } \\
\text { (Ostrów Tumski), } \\
\text { Dolnośląskie } \\
\text { Voivodeship }\end{array}$ & $\begin{array}{l}2265 \text { fragments } \\
\text { of glass vessels } \\
\text { / } 33 \text { (?) bottle } \\
\text { fragments }\end{array}$ & 5 seals & $\begin{array}{l}\text { a descriptive sign - with the } \\
\text { name of the town and glass } \\
\text { workshop (Corin), monograms } \\
\text { (H E; K R Q; K), shape } \\
\text { (triangle) }\end{array}$ & $\begin{array}{l}\text { Modern } \\
\text { Period }\end{array}$ & $\begin{array}{l}\text { Siemianow- } \\
\text { ska } 2015\end{array}$ \\
\hline
\end{tabular}

* calculations made by the author based on data included in the publication 


\section{Observations made on the basis of the current state of research}

Based on the collated data it is possible to state unequivocally that vessels with such seals and such loose finds are relatively rare. The total number of artefacts listed in Table 1, covering 24 regions of archaeological excavations, was over 220 specimens. Other sites (around 60 in total), where archaeologists discovered glass seals (overall at least 330) and which were mentioned in publications from that time include: Bierzwnik, ${ }^{13}$ Biskupice, ${ }^{14}$ Breń, ${ }^{15}$ Chełmno, ${ }^{16}$ Darłowo, ${ }^{17}$ Fordon, ${ }^{18}$ Gdańsk, ${ }^{19}$ Gdańsk - Wisłoujście, ${ }^{20}$ Gniewkowo, ${ }^{21}$ Inowrocław, ${ }^{22} \mathrm{Je}$ leńcz, ${ }^{23}$ Karczyn, ${ }^{24}$ Koszalin, ${ }^{25}$ Krosno Odrzańskie, ${ }^{26}$ Łabiszyn, ${ }^{27}$ Lomża, ${ }^{28}$ Lódź, ${ }^{29}$ Myślibórz, ${ }^{30}$ Pakość, ${ }^{31}$ Poznań, ${ }^{32}$ Poznań - Ostrów Tumski, ${ }^{33}$ Przeborowo, ${ }^{34}$ Radom, ${ }^{35}$ Radoszyce, ${ }^{36}$ Słaboszewo, ${ }^{37}$ Stargard, ${ }^{38}$

${ }^{13}$ Glass workshop, total number of glass seals - 81 (Markiewicz 1999, 180, no figures), including: 46 seals (Stolpiak and Świercz 1997, 42-45, no figures) and 13 seals (Stolpiak and Świercz 1998, 39-41, no figures).

${ }^{14}$ Church, 1 seal (Ruszkowska 2007, 148, Fig. 3:6; 149-150).

${ }^{15}$ Glass workshop, 1 seal (Mucha 1994, 68, 79, Fig. 10:2).

${ }^{16}$ Near monastery, 3 seals (Olczak 1991, 78-79, Fig. 5).

${ }^{17}$ Old Town, 3 seals (Kuczkowski 2016, 161-162, nos. 1.1-1.3).

${ }^{18}$ Town, 20 seals, including: 17 seals (Woźny 2001, 248-251) and 3 seals (Siwiak 2003, 60-61).

${ }^{19}$ Town, 8 items, including: 3 seals (Krukowska 2007a, 434435) and 5 seals (Zespół Przedbramia, Krukowska 2016, 212-215, Fig.4).

${ }^{20}$ Fortress, 3 seals (Szczepanowska 2015, 307-310, Fig. 108:19).

${ }^{21}$ Village, 5 seals (Sulkowska-Tuszyńska 2018, 123-124; 195, Figs. 92-93)

${ }^{22}$ Old Town, 36 seals (Siwiak 2007b, 77).

${ }^{23}$ Settlement (?), 1 seal (Siwiak 2004, 157-158, Fig. 1:a).

${ }^{24}$ Settlement, 1 seal (Siwiak 2007b, 78-79, Fig. 1:4).

${ }^{25}$ Old Town, 3 items, including: 2 seals and 1 bottle with seal (Borkowski and Kuczkowski 2011, 45, Fig. 34:1-1; 97, Fig. 107).

${ }^{26}$ Castle, 1 seal (Dziedzic and Kałagate 2002, 77 and 162, Pl. IX:1).

${ }^{27}$ Castle, 5 seals (Siwiak 2007a).

${ }^{28}$ Town, at least 3 seals, including: undefined number of seals and 1 published (Jurzysta 2014, 103), as well as 1 seal (Bienia 2014, 151).

${ }^{29}$ Town, 1 seal (Dziubek et al. 2002-2003, 368, 380, Fig. 6:5).

${ }^{30}$ Town, 1 seal (Szymczyk 2016, 551).

${ }^{31}$ Monastery, 1 seal (Siwiak 2007b, 78-79, Fig. 1:2-3).

${ }^{32}$ Town, undefined number of seals, 1 published (Wawrzyniak 2000, 74, Fig. 17).

${ }^{33}$ Town, 5 seals and one mark left by the seal on a fragment of a glass bottle (Antowska-Gorączniak 2012, 151, 194, P1. 6:1-5).

${ }^{34}$ Glass workshop, 2 seals (Mucha 1997, 118 and 114, Fig. 3).

${ }^{35}$ Castle, 1 seal (Lechowicz 2012, 124, [Fig.] 108).

${ }^{36}$ Castle, 1 seal (Kajzer 1988, 143).

${ }^{37}$ Settlement, 1 seal (Siwiak 2007b, 79).

${ }^{38}$ Stargard, Old Town, total number: 86 seals, including: 2 seals (Burdziej et al. 2013, 348); 6 seals (Burdziej et al. 2013, 350, 374 , Fig. 28:3-7, 10); 1 seal (Burdziej et al. 2013, 352, 379, Fig. 32);
Strzelno Klasztorne, ${ }^{39}$ Toruń, ${ }^{40}$ Trzemeszno, ${ }^{41}$ Warsaw, ${ }^{42}$ Warsaw - Royal Castle, ${ }^{43}$ Warsaw - Wilanów, ${ }^{44}$ Witów, ${ }^{45}$ and Wrocław. ${ }^{46}$

The total number of all finds mentioned in the collected publications would be at least 550 . These numbers are only of an informative nature, as in several cases (Łomża, ${ }^{47}$ Poznań, ${ }^{48}$ and Trzemeszno) ${ }^{49}$ the number of glass seals obtained from excavations was not specified in detail. No doubt, at a national level the number of the discovered seals is much higher, but those finds have not been mentioned in published research results. ${ }^{50}$

Usually, on one site there were several to around a dozen of such finds. Greater numbers (several dozen specimens) were obtained only in a few cases, during archaeological excavations covering large areas - the Old Town in Elblag (37 specimens), the area of the Augustinian church in Stargard (33?), and Plac Zamkowy (Royal Palace square) in Warsaw (59), as well as finds from the Old Town in Stargard (86 in total), ${ }^{51}$

49 seals (Burdziej et al. 2013, 353-354, 384, Fig. 39); 3 seals (Burdziej et al. 2013, 360, Fig. 69:4); 2 seals (Burdziej et al. 2014, 281, 291, Fig. 17:1-2); 11 seals ( 8 seals published, Burdziej et al. 2014, 378, 380, Fig. 11:1-8 and information about 11 seals, Szeremeta 2018, 390, 392, Fig.5:1-8); 10 seals (Burdziej et al. 2014, 382, 389, Fig. 19:6-12); 1 seal (Bucka et al. 2015, 488, 491, Fig. 17:3); Old Town Market, 1 seal (Majewski 2017, 103-104, 106, Fig. 1:7). Stargard, town, total number: 13 seals, including: 5 seals (Kwiatkowski 2010, 103-104; 108, [Fig.] 8); 1 seal (Burdziej et al. 2013, 348349); 5 seals (Burdziej et al. 2013, 349); 1 seal (Burdziej et al. 2013, 352, 379, Fig. 33); 1 seal (Bucka et al. 2017, 224).

${ }^{39}$ Settlement (?), 1 seal (Siwiak 2004, 157-158, Fig.1:a).

${ }^{40}$ Old Town, 2 seals, including: 1 fragment of a glass bottle with a glass seal (Rubnikowicz 1989b, 76-77, Pl. II:1) and 1 seal (Siwiak 2007b, 80, footnote 20).

${ }^{41}$ Monastery, several fragments of glass bottles with seals (Wiewióra 2000, 201-202, Fig. 90:5-6).

${ }^{42}$ Ogród Krasińskich, 2 seals (Meyza 2014, 34, 37, P1. III: 1-2); town, 7 round seals (Lipiec 2017, 172-173, Fig. 5); Plac Zamkowy, 3 glass bottles with glass seals (Kozłowska 1994, 38 , nos. 101-102; 39, no. 104).

${ }^{43} 2$ glass bottles with glass seals (Kozłowska 1994, 36, no. 95; 41 , no. 110$)$

${ }^{44} 1$ seal without imprint (Andrzejewska et al. 2002-2003, $300)$.

${ }^{45}$ Monastery, 1 seal (Andrzejewski and Kajzer 2001, 334).

${ }^{46}$ Old Town, 1 fragment of a glass bottle with a glass seal (Nowosielska 1998, 250-251).

47 Jurzysta 2014, 103.

${ }^{48}$ Wawrzyniak 2000, 74.

${ }^{49}$ Wiewióra 2000, 201-202.

${ }^{50}$ This is indicated by, among other things, information concerning finds from Bydgoszcz. Wojciech Siwiak in his work from 2009 stated that the total number of glass seals obtained to date from the area of the town was approximately 200 (Siwiak 2009, unpaged), whereas publications contain descriptions of only 43 specimens from modern-day Bydgoszcz (including: 23 items, Siwiak 2002; Siwiak 2009; and separately listed 20 items from Fordon, Woźny 2001; Siwiak 2003).

${ }^{51}$ See footnote 38 . 
from the Old Town in Inowrocław (36 items), ${ }^{52}$ and the Cistercian monastery in Bierzwnik (Marienwalde) $(81),{ }^{53}$ the location of a post-medieval glass workshop..$^{54}$

The percentage of glass seals and glass vessels with seals compared to the total number of discovered storage bottles usually ranged between $1-4 \%$, sometimes below $1 \%$, and only in rare cases was as high as $10 \%$ (for the assemblage of finds from the castle in Toruń). The percentage of signed vessels compared to the total number of glass fragments discovered at individual sites was even lower $-0.1-0.6 \%{ }^{55}$ Although these values give us only approximate information due to the selective nature of the compilation created for this paper, they still provide us with some notion of the scale of the phenomenon consisting in the use and presence of glass seals on the territory of Poland in the modern period. That low percentage may be the result of a number of factors. However, in this context, assumptions concerning the signing of only specific batches, series of products made to special (also individual) orders, seem to be fully justified.

The dating of the finds included in the discussed compilation generally falls to the period between the end of the $17^{\text {th }}$ century to the second half of the $19^{\text {th }}$ century, rarely exceeding either of these thresholds (the earliest dates being those concerning finds from the excavations at the site of the town hall in Łowicz - from around the second half of the $17^{\text {th }}$ century and the tower castle in Siedlęcin as well as the Old Town in Elbląg the latest - until the 1890s). This conforms with the conclusions regarding the production and use of similar signs in western European countries. ${ }^{56}$

Vessels with seals are usually standard products, of average quality, most common on the market, and do not differ from unsigned specimens. ${ }^{57}$ They are made

${ }^{52}$ Siwiak 2007b, 77, footnote 6 .

${ }^{53}$ For brief information on these finds see Markiewicz 1999, 180; see also Stolpiak and Świercz 1997, 42-45; Stolpiak and Świercz 1998, 39-41.

${ }^{54}$ The latter three assemblages were not included in Table 1, due to insufficient information contained in publications about these finds.

${ }^{55}$ This remains in line with the findings made by Andrzej Gołębiewski, who in his work published 23 years ago (likewise based on the literature and archaeological finds available at that time) also estimated that the "percentage of bottles with impressed stamps in the preserved assemblages did not reach even 1\%" (Gołębiewski 1997, 184).

${ }^{56}$ Among others, Morgan 1976; Dumbrell 1983.

${ }^{57}$ See Gołębiewski 1997, 185. At the beginning of the $19^{\text {th }}$ century, the best and the most durable Polish bottles (appropriate for fizzy drinks and with a quality similar to that of English bottles) were believed to be vessels from Huta Sztabińska - glass workshop located in the village of Sztabin in Podlasie region (Włodarczyk 2017,145 , footnote 15). Currently there is only one artefact among from green, greenish, or brown glass, with visible air bubbles. Since seals are usually found separately, with only small fragments of the bodies (upper parts of bottles), in most cases it was not possible to establish the specific shape and size of the vessel. They survived in Elbląg ${ }^{58}$ and Warsaw. ${ }^{59}$ They were attached to storage bottles with a round (cylindrical) or oval cross-section, as well as rectangular bottles (i.e. flasks), ${ }^{60}$ in the place where the neck transforms into the body (on the shoulder) and where glass is thinner and more fragile, which possibly made those batches of glass products more prone to damage.

Due to the fragmentary preservation of the majority of vessels and the still small available source database, no correlations between the shape of the container and a specific type of markings were observed. In this respect, the only link is associated with finds with different versions of the name "London", which - based on descriptions provided by authors or figures of finds - more often are rectangular vessels. Their shape was adjusted for transporting them in travel cases (case bottles). However, the search for more specific relationships between individual vessels and details of representations on the seals at this stage would be premature. Among Polish finds, we may only observe a greater proportion of cylindrical bottles than squat ones (representing the following types: shaft and globe, onion bottles, and malet bottles). This is linked to the chronology of Polish finds, as they are mainly vessels from the $18^{\text {th }}$ and $19^{\text {th }}$ centuries, which saw a gradual increase (and then the dominance) of such slenderer forms. ${ }^{61}$

Seals usually have small sizes, with diameters of around 3-4 $\mathrm{cm}$ and thickness below $3 \mathrm{~mm}$. They are usually round (e.g. Figs. 1 and 2); only in few cases records showed a rectangular imprint, among finds from Warsaw (Fig. 7:b; another example see Fig. 2:c). ${ }^{62}$ This was the result of using a tool with an appropriate section. They also usually have a visible, convex rim made by the pressure created by the stamp being applied to the hot glass disc while attaching it to the

the published archaeological finds known from Łomża (Jurzysta 2014, 103; there is no figure depicting the seal).

${ }^{58}$ Gołębiewski 1997, 185.

${ }^{59}$ Kozłowska 1994, 36, 38-39, 41; Baturo 2017, 201-217.

${ }^{60}$ In the analysed archaeological materials I did not find any information about discoveries of bottles with glass seals that would have other shapes, for instance with triangular or octagonal bodies, which would also be manufactured around that time (such artefacts are mentioned in, e.g. Morgan 1976, 58-59, 68; Dumbrell 1983, 87-90, 141).

${ }^{61}$ See e.g. Morgan 1976, 24-27; Dumbrell 1983, 100-119.

${ }^{62}$ Baturo 2017, P1. 5:4; Baturo and Kasprzak 2018b, 30, Figs. 1-2. 


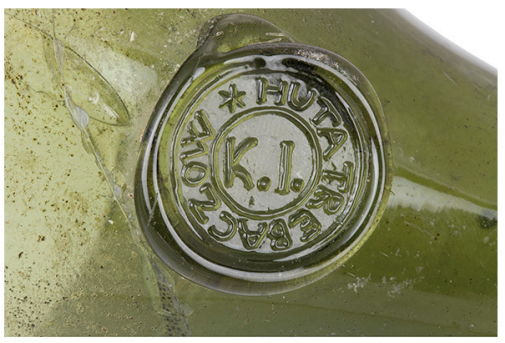

a

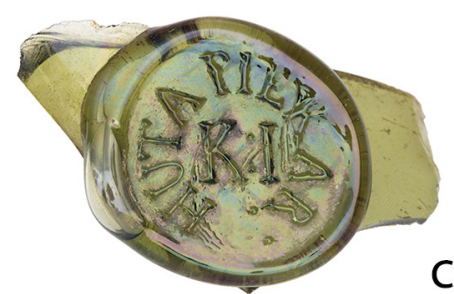

C

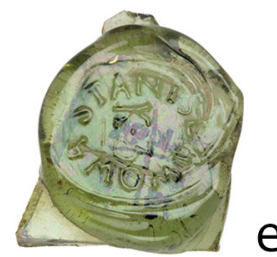

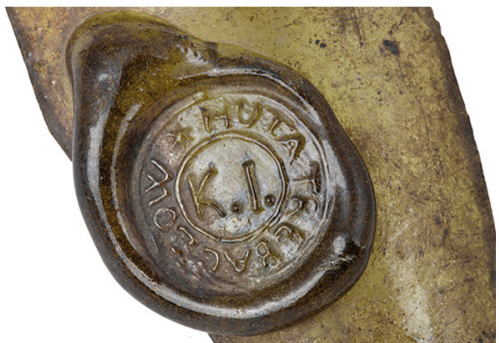

b

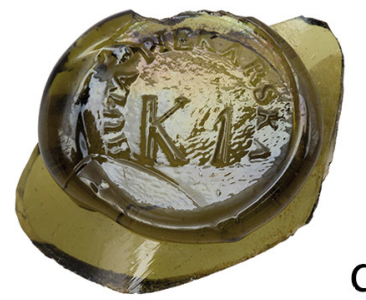

d

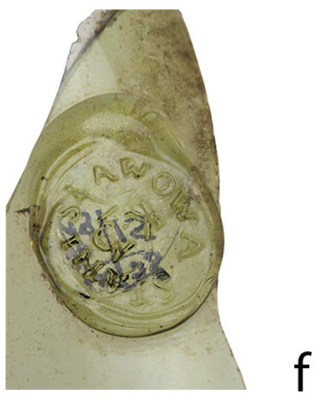

Fig. 1. Examples of glass seals from the end of the $18^{\text {th }}$ - beginning of the $19^{\text {th }}$ century. Unpublished Polish finds from the Tin-Roofed Palace in Warsaw: a-b - from Trębaczów glass workshop; c-d - from Piekarska glass workshop (in Piekary); e-f - from Stanisławów glass workshop. After Bis 2020b, Fig. 4. Photo M. Osiadacz.

surface of the bottle and constituting the excess of glass mass gathered around the imprint (other examples see Figs. 1 and 2:a-b, d).

Much less often the stamp is on the glass strip below the lip of the bottle (Fig. 3). ${ }^{63}$ It is a separate and at the same time a simplified manner of signing glass containers, with a similar marketing as well as fiscal and inspection function. The signs were placed along a flattened circular glass tape (around $0.5-1 \mathrm{~cm}$ wide) under the rim of a bottle. ${ }^{64}$ In exceptional cases, they

${ }^{63}$ Polish researches call them signature discs (Gołębiewski 1997, 201) or signature strips (e.g. Baturo and Kasprzak 2019a).

${ }^{64}$ For this reason, it was not necessary to carry out additional technological actions consisting in the production of a glass disc. Such finds were recorded on several occasions: in Elbląg (11 finds, Gołębiewski 1997, 201), in Warsaw - the Old Town area (7 items, including: 2 specimens, Baturo and Kasprzak 2019b, 38; 3 specimens, Baturo and Kasprzak 2019c, 28-29; 2 specimen, Baturo and Kasprzak 2018c, 37) and the town (6 items, Lipiec 2017, 170-173, Fig. 1:c, 2:b; Fig. 3:a; Fig. 5:a, i-j, k), the monastery in Pakość (2 items, Siwiak 2007b, 78-79, Fig. 1:2-3) and the village take the form of a quadrangular imprint.$^{65}$ Markings on glass tapes are schematic, limited to letters (including unrelated, not forming legible inscriptions) and combinations of letters and numerals referring to the serial numbers of products or beverages, capacity, etc. ${ }^{66}$ (Fig. 3:a-d), without any pictograms. In a few cases they bear the name of a glass works ("H IEZEWIC:" or "H: IE[...]", "H:LUTKOWSKA", "H:SWYNC:", ${ }^{67}$ "H: WALOWI") ${ }^{68}$ (Fig. 3:e-f). Based on the collected material from Poland, it is possible to state that this method of counting post-medieval glass bottles was used much less often than the glass seals method.

in Zajezierze (1 specimen, Siwiak 2004, 159). The total number of above mentioned items is 27 .

${ }^{65}$ Lipiec 2017, 171, Fig. 6:a.

${ }^{66}$ See also Gołębiewski 1997, 200-201, Fig. 4:a-f.

${ }^{67}$ The same inscriptions are the imprints on round glass seals, see Baturo and Kasprzak 2018c, 37, Figs. 1-3; Baturo and Kasprzak 2019a, 26-17; Baturo and Kasprzak 2019c, 28-29, Figs. 1-4.

${ }^{68}$ Baturo and Kasprzak 2019b, 38, Figs. 1-2. 


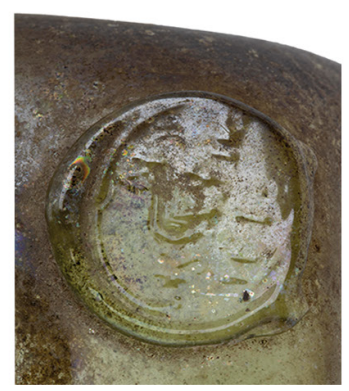

a

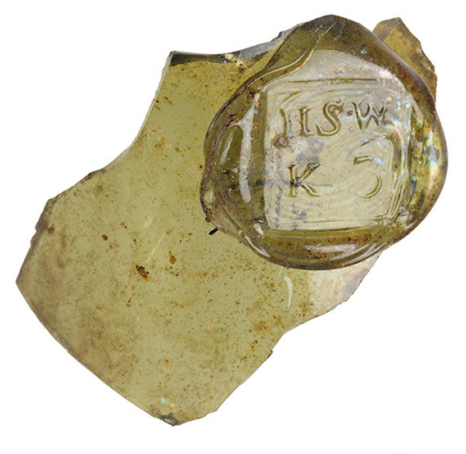

C

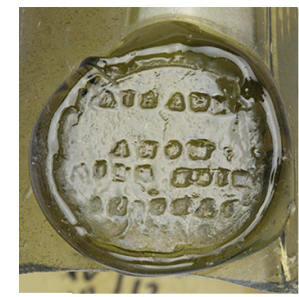

b

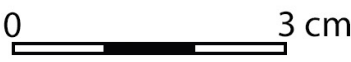

Fig. 2. Examples of glass seals from the end of the $18^{\text {th }}$ - beginning of the $19^{\text {th }}$ century. Unpublished Polish finds from the Tin-Roofed Palace in Warsaw: a-b - with illegible seals; c-d - with unidentified seals. After Bis 2020b, Fig. 6. Photo M. Osiadacz.

Seals differ in terms of their types, i.e. signs placed on seals and their iconography. These include individual signs, trademarks, monograms, as well as symbols, descriptive signs, and numerical signs. ${ }^{69}$ They have the form of positives - raised imprint on a concave background. They are usually made shoddily, without much care about details of the drawing and the shape of letters. In many cases they were impressed unevenly, thus only a part of the original stamp is visible. Most probably this was caused by the intensive use of presses for creating imprints. If glass mass stuck to the surface of presses, symbols and inscriptions on subsequent imprints would become blurred. Thus, the period of their suitability for use could be quite short. ${ }^{70}$ However, the examples analysed here show that those tools must have been used despite their faults, causing impressed images to be increasingly illegible. Another

\footnotetext{
${ }^{69}$ Types of signs on seal identified by A. Gołębiewski based on finds from the Old Town in Elbląg (Gołębiewski 1997, 187). I use that classification while discussing signs on glass seals in this paper. Only in the case of signs containing names of glass workshops I allocate them to the group of descriptive signs and not trademarks, as in my opinion, the first term provides a better characteristic of inscriptions on the analysed artefacts.

${ }^{70}$ See Friese 1995, 20.
}

explanation of the above-mentioned defects could be impressing the stamp in still too molten glass, as well as insufficient skill on the part of craftsmen creating matrices that were necessary for making presses, the latter becoming worn out, or because of the haste or shoddiness of glasshouse workers.

According to the review of published finds from Poland, the dominating type are descriptive signs, i.e. with names of glass workshops and names of places in which they were located. They appear as full words or abbreviations, without diacritic signs or misspelled. They include, among other things, markings associated with glass workshops from the territory of Western Pomerania (Fig. 4), which - as indicated by the data presented here - are currently represented by the greatest number of identified and relatively well dated specimens, mainly from Bydgoszcz (as well as from Fordon, which currently is part of Bydgoszcz), Elbląg and Stargard. The following glass workshops have been identified:

"BAERENWALDE" (Bärenwalde - Mysia Dziu$\mathrm{ra},{ }^{71}$ Bincze $^{72}$ or other, located near Chojnice and

\footnotetext{
${ }^{71}$ Gołębiewski 1997, 192-193, Fig. 2:a-b, d, f.

${ }^{72}$ Siwiak 2009, unpaged.
} 

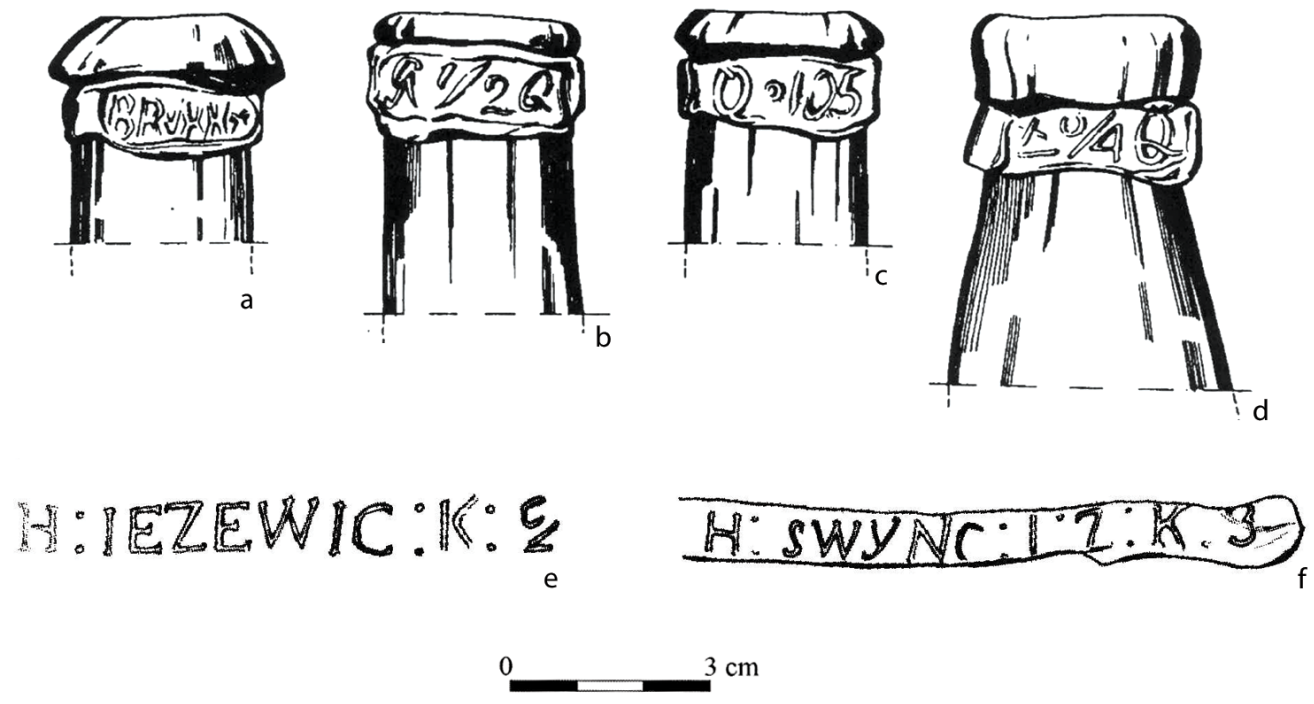

Fig. 3. Examples of signs on the glass strip below the lip of the bottle from the $17^{\text {th }}-19^{\text {th }}$ century discovered in Poland: a-d - finds from Elbląg. After Gołębiewski 1997, 200, Fig. 4:a-d; e-f - finds from Warsaw. After Lipiec 2017, 172, Fig. 5:j, k.

Kościerzyna) ${ }^{73}$ (Fig. 4:a-c); "BATTROW” (probably Batorowo) $7^{74}$ "BERNSEE" (Breń, 1660-1822/1824) (Fig. 4:y); “CANTRECK” (Łoźnica, 1806-1875) (Fig. 4:u-w); "FABRIQUE GRUNAU" (Gronowo) (Fig. 4:d-e); "LOTZEN" (Łośno, 1746-1785); as well as "MARIENWALDE" (Bierzwnik, 1607-1822/1824) 75 (Fig. 4:i-j, m-p). The remains of the latter glass workshop have been investigated by archaeologists. During excavation works carried out before 1999 archaeologists discovered in total 81 glass seals. ${ }^{76}$ Those finds have not yet been fully published.

Other glass workshops that operated in that area and were identified on the basis of glass seals include: "MEHRENTHIN" (Mierzęcin?, 1797-1875) (Fig. 4:g); "PIEPSTOCK" (Podlipce, 1750 - after 1855) (Fig. 4:qt); "PPOWO" (Chłopowo?); 77 furthermore "GLAS FABRIK CLEMENTIENHOF" and "[C]LEMENTIN" in

\footnotetext{
${ }^{73}$ Sulkowska-Tuszyńska 2018, 123, 195, Fig. 93:c.

${ }^{74}$ Sulkowska-Tuszyńska 2018, 123, 195, Fig. 92:a.

${ }^{75}$ Woźny 2001, 246, Fig. 1:5-6; 247, Fig. 2:1; 249-250; Siwiak 2007b, 77, footnote 6 . Cnotliwy 2014, 278. The name of the glass works in Marienwald is known in different versions from the seals found in Stargard, e.g.: "KON PR MARIENWALDSCHE GLASFABRIQUE" (Burdziej et al. 2013, 349, 353). Other finds from Stargard, e.g.: Burdziej et al. 2013, 348-350; Bucka et al. 2015, 491, Fig. 17:3; Bucka et al. 2017, 224; Wilgocka 2016, 227; Szeremeta 2018, 390 .

${ }^{76}$ Stolpiak and Świercz 1997, 42-45; Stolpiak and Świercz 1998, 39-41; Markiewicz 1999, 180.

${ }^{77}$ Gołębiewski 1997, 192-195; finds from Stargard, e.g.: Kwiatkowski 2010, 103, 108, Fig. 8; Burdziej et al. 2013, 354; Wilgocka 2016, 227-228, 238, Fig. 5; finds from Fordon: Woźny 2001,
} 250-251. modern-day village of Klementynowo; "GL[AS] FABRIK THURE" or "[GL]AS FA[BRIK] [THURMUHL]" (in Tur, from 1842 or 1845$)^{79}$ (Fig. 4:h), and Lipusz, with many spelling variations: "LIPPUSCH", 80 "LIPUSCH", ${ }^{81}$ "IPPUS" and "IPPUSCH" the relevant inscriptions - "[ST]UTHOF" other glass workshop that manufactured glass bottles with seals was located in the village of Stuthof (currently within the administrative area of Szczecin) and operated from 1821 until the mid- $19^{\text {th }}$ century.

Products of five more glass workshops were also registered: „HAMMERSCHE GLAS FABR.” ${ }^{\prime 4}$ or “HAMMER Glas F" (Hammer[sche] Glas F[abrik]) (Rudnica, 1749-1855) (Fig. 4:f); as well as unspecified "GLAS MÜHL" - on seal found in Gniewkowo, ${ }^{85}$ ANNENWALDE" (modern-day Germany, Brandenburg, 17551867) and "GRIMTZ" (Grimnitz, located near Potsdam), which are also known, e.g. from finds discovered in Szczecin, ${ }^{86}$ whereas from Wrocław comes the seal

\footnotetext{
${ }^{78}$ Siwiak 2007a, unpaged, Fig. 7:1-2; Siwiak 2007b, 78-79, Fig. 1:2

${ }^{79}$ Sulkowska-Tuszyńska 2018, 123, 195, Fig. 93:a; Siwiak 2004, 157-158, Fig. 1:a; Siwiak 2007b, 78-79, Fig. 1:3-4.

${ }^{80}$ Kuczkowski 2016, 162, no. 1.3; Woźny 2001, 247, Fig. 2:2.

${ }^{81}$ Starski 2015, 160-163, Fig. 141:2.

${ }^{82}$ Gołębiewski 1997, 194, 200, Fig. 4:g, h.

${ }^{83}$ Wilgocka 2016, 228, 239, Fig. 6:6-7.

${ }^{84}$ Woźny 2001, 247, Fig. 2:3; 251; Siwiak 2007a, unpaged; also on find from Myślibórz (Szymczyk 2016, 551) and probably on the item from Krosno Odrzańskie (Dziedzic and Kałagate 2002, 77, 162, Pl. IX:1).

${ }^{85}$ Sulkowska-Tuszyńska 2018, 123-124; 195, Fig. 93:b.

${ }^{86}$ Cnotliwy 2014, 277-278. The author incorrectly identified the latter seal as coming from the town of Krynica. Another item
} 

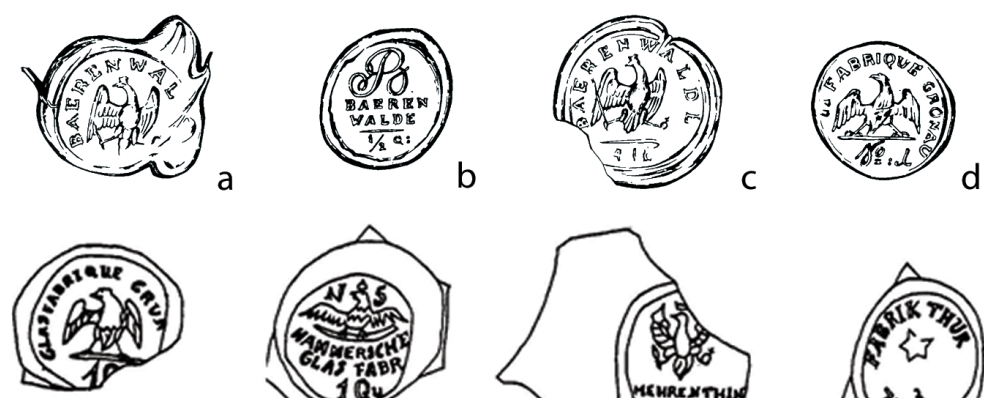

e
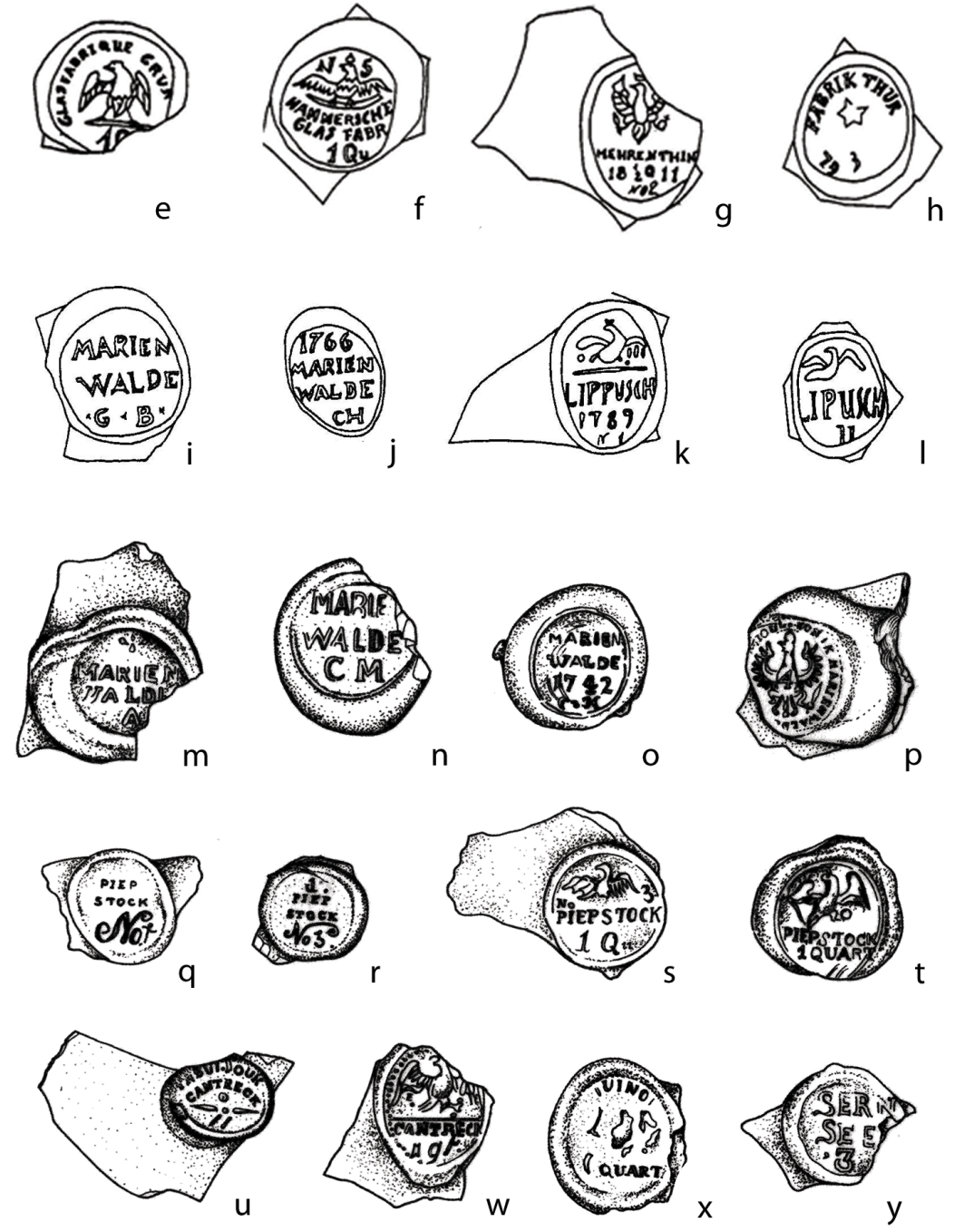

Fig. 4. Examples of glass seals with signs representing individual glass workshops in Western Pomerania from the $17^{\text {th }}-19^{\text {th }}$ century discovered in Poland : a-d - finds from Elbląg. After Gołębiewski 1997, 193, Fig. 2:a-d; e-l - finds from Fordon. After Woźny 2001, 246 ,

Fig. 1:5-6, 8-9; 247, Fig. 2: 1-4; m-y - finds from Stargard. After Wilgocka 2016, 238, Fig. 5:1-2, 5-6, 9-10, 12, 14, 17-18; 239, Fig. 6:1, 6.

"CORIN", which refers to the glass workshop located in Chorin, near Eberswalde (in Brandenburg). ${ }^{87}$ Associating the newly discovered artefacts from that area with the functioning of individual workshops is facilitated by the already available publications of German researches concerning glass workshops and their trademarks. ${ }^{88}$

related to the glass workshop in Annenwalde was found in Breń, Mucha 1994, 68, 79, Fig. 10:2.

${ }^{87}$ Siemianowska 2015, 224, Fig. 10:g. The author did not identify the manufacturer of that artefact.

${ }^{88}$ In particular Friese and Friese 1992; Humbsch 2001; Humbsch 2002; Humbsch 2006.
Markings associated with Mazovian glass workshops (Fig. 5:a-g) - several workshops located near Warsaw, which recently became the subject of research focusing on the recording of finds and their correlations with written records and cartographic sources. These workshops are characterised by the following signs discovered during excavations carried out in Warsaw: "BLENDOW” and „BLENDO” (a glass workshop that operated in Błędów, in the years 1801-1806/1807) ${ }^{89}$ (Fig. 5:d-e); "H: JEZEWIC:” (Huta Jeżewicka - Jeżwice

${ }^{89}$ Kozłowska 1994, 38, no. 101; Baturo 2017, 221; Baturo and Kasprzak 2018b. 


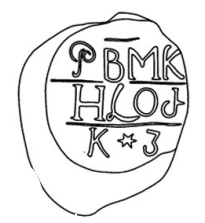

a
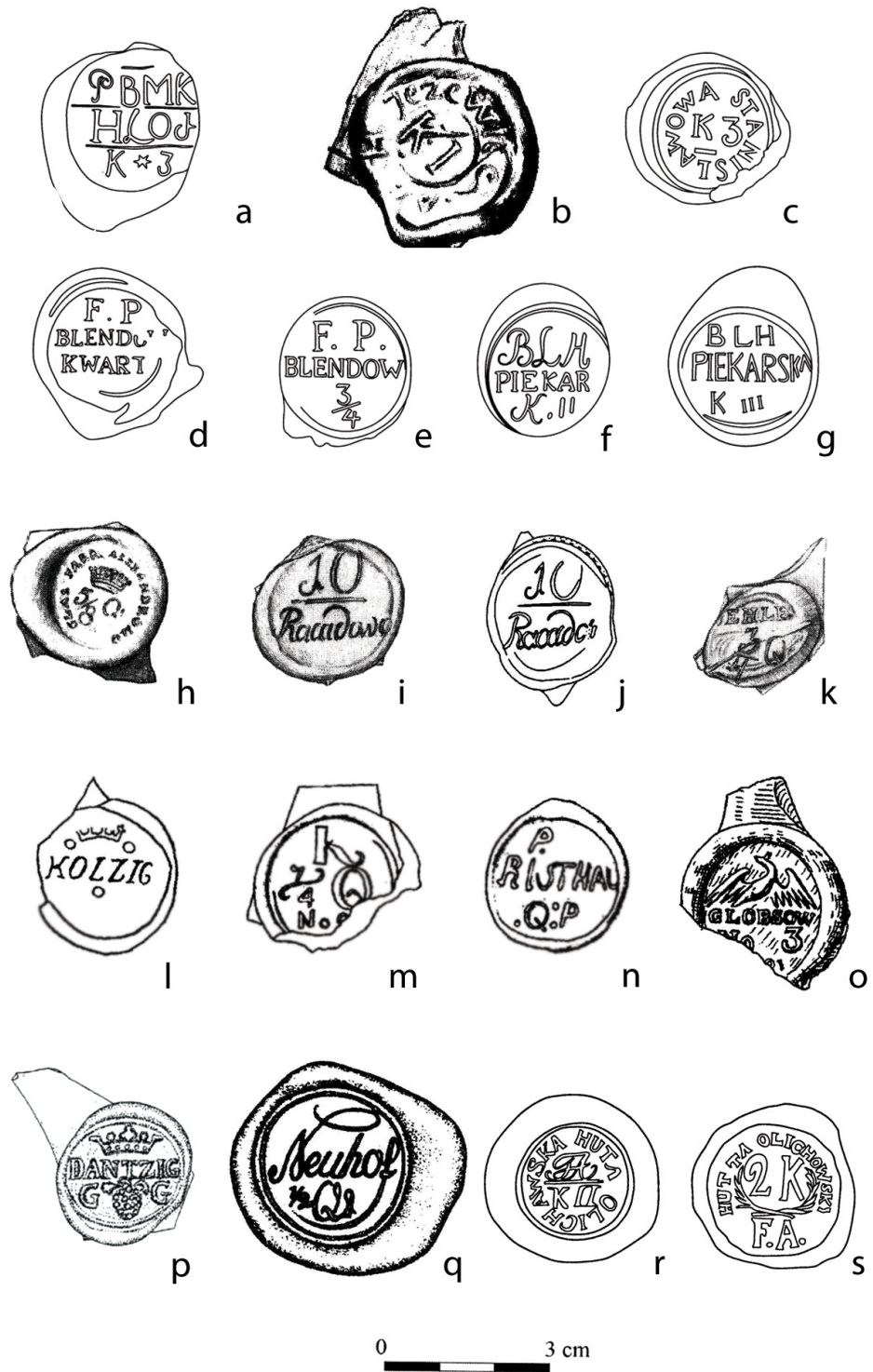

Fig. 5. Examples of glass seals with signs representing individual glass workshops in Mazovia (a-g), in Greater Poland (h-k, o), in Silesia (1-n), in Gdańsk Pomerania ( $\mathrm{p}-\mathrm{q})$, and unidentified glass workshops ( $\mathrm{r}-\mathrm{s})$ from the $17^{\text {th }}-19^{\text {th }}$ century discovered in Poland: a-g - finds from Warsaw. After Baturo 2017, 235, Pl. 5:5, 9, 17-20; Lipiec 2017, 172, Fig. 5:g; h-i, k - finds from Poznań. After Antowska-Gorączniak 2012, 194, Pl. 6:1, 3-4; j - find from Fordon. After Siwiak 2003, 60, Fig. 1:2; 1-n - finds from Siedlęcin. After Grabny 2016, 271, Pl. 2:9-11; o - find from Przeborowo. After Mucha 1997, 114, Fig. 3:1; p-q - finds from Gdańsk. After Krukowska 2007a, 434,

Fig. 4; Krukowska 2016, 213, Fig. 4:c; r-s - finds from Łowicz. After Poturalska 1999, 319, Fig. 1:2-3.

glass workshop, 1836-1840, previously Huta Tartak Tartak glass workshop, 1835-1836) ${ }^{90}$ (Fig. 5:b); and "H: WALOWI" (Huta Wałowska - Wałowska glass workshop, 1830-1839); ;1 as well as "HEINZ STRZIZE" (in Strzyżewskie Budy);9 "HLO" (in Łochów) ${ }^{93}$ (Fig. 5:a); "PIEKARSKA", also spelled "PIEKARY"

${ }^{90}$ Baturo and Kasprzak 2019c; other finds: Lipiec 2017, 172-

173, Fig. 5:a, f-h, j.

${ }^{91}$ Baturo and Kasprzak 2019b.

92 Baturo 2017, 220

${ }^{93}$ Baturo 2017, 219. (in Piekary, c. 1803-1839) ${ }^{94}$ (Fig. 5:f-g; other examples Fig. 1:c-d); and „STANISLAW" 95 or "STANISLAWOWA" (in Stanisławów, which operated in two stages: the first glass workshop - 1796-1801/1803; and the second glass workshop - 1805-1806?) ${ }^{96}$ (Fig. 5:c; other examples Fig. 1:e-f).

Production was also confirmed in glass works located in Lutkówka (in the years 1838-1851/1852),

\footnotetext{
${ }^{94}$ Baturo 2017, 221-222.

${ }^{95}$ Kozłowska 1994, 41, no. 110.

${ }^{96}$ Baturo 2017, 219; Baturo and Kasprzak 2018d.
} 

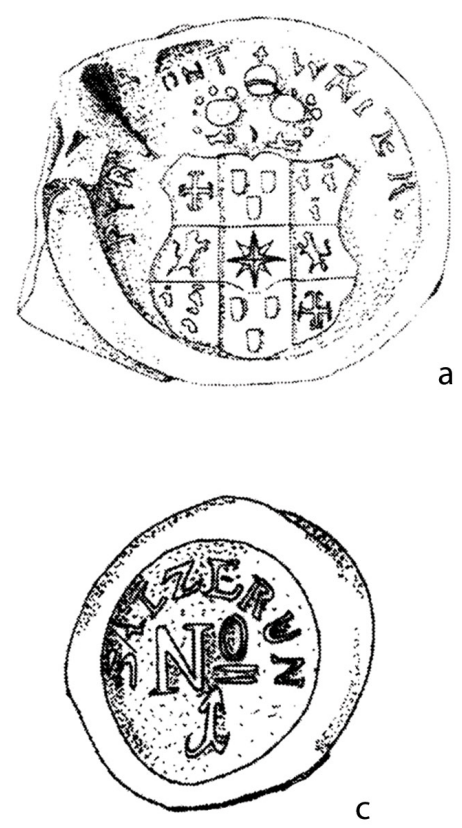

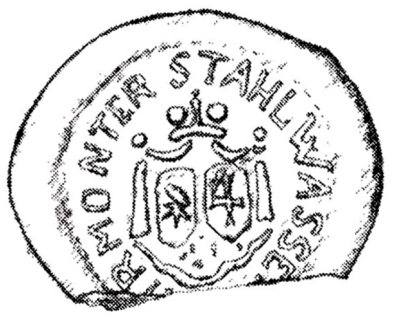

b
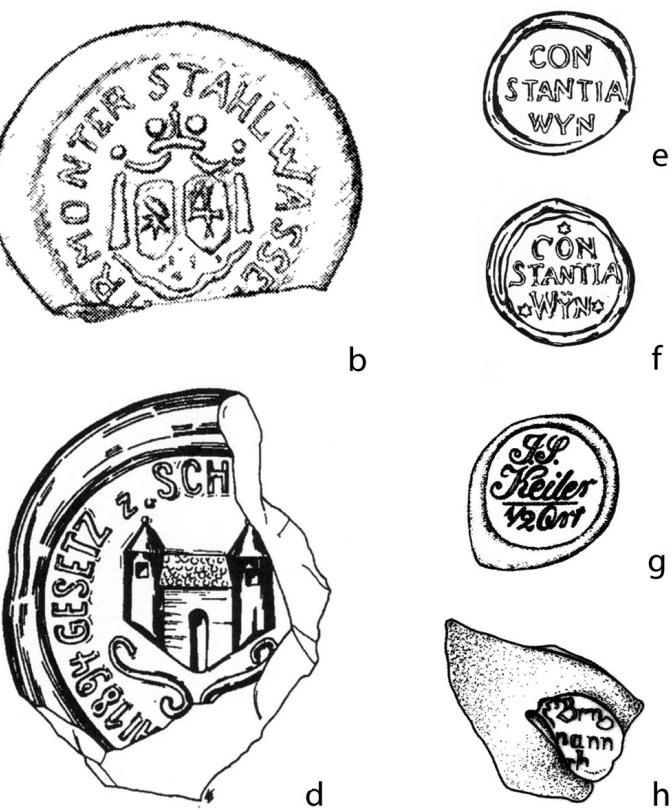

g

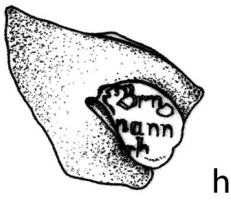

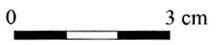

Fig. 6. Examples of glass seals with signs representing glass workshops that operated in more distant locations (a-c, e-f), as well as glass seals with heraldic signs (a-b, d) and with names and surnames (e-h) from the $17^{\text {th }}-19^{\text {th }}$ century discovered in Poland: a-c, h - finds from Stargard. After Wojciechowska 2015, 199, Fig. 9:1-3; Wilgocka 2016, 239, Fig. 6:5; d-f - finds from Elbląg.

After Gołębiewski 1997, 197, Fig. 3: b-c; 200, Fig. 4:i; g - find from Gdańsk. After Krukowska 2016, 213, Fig. 4:b.

as evidenced by the seal "H: L[UT]KOWSKA" (1838-1851/1852), ${ }^{97}$ and in Świnice (1829-1838), as well as in Trębaczów (1819-1829), the material evidence of which are seals, respectively, with the name "H:SWYNC" (Fig. 3:f) or "HUTA TREBACZOW" (other examples see Fig. 1:a-b).

Seals associated with glass workshops in Greater Poland (3): "RACADO[W]", "RACADOWO" (in Racendów near Kotlin, on maps recorded as Racendower Glashütte, which operated from the end of the $18^{\text {th }}$ century and in the $1^{\text {st }}$ half of the $19^{\text {th }}$ century) found on artefacts from Poznań ${ }^{100}$ and Fordon ${ }^{101}$ (Fig. 5:i-j); as well as "[B]EHLE" (in the village of Biała near Czarnków, which operated in the years 1800-1850) (Fig. 5:k), and "GLAS Fabr Alexandrowo" (in Aleksandrów, 1815-1866) on seals from Ostrów Tumski in Poznań ${ }^{102}$ (Fig. 5:h).

Silesian glass workshops (2) were identified in the basis of the following the signatures: "KOLZIG", "K", ${ }^{103}$ and "[C]RLSTAHL" found on pieces of glass

\footnotetext{
${ }^{97}$ Baturo and Kasprzak 2018c.

${ }^{98}$ Lipiec 2017, 172, Fig. 5: i, k; Baturo and Kasprzak 2019a,

${ }^{99}$ Baturo and Kasprzak 2018a.

${ }^{100}$ Antowska-Gorączniak 2012, 151; 194, Pl. 6:4.

${ }^{101}$ Siwiak 2003, 60, Fig. 1:20.

${ }^{102}$ Antowska-Gorączniak 2012, 151; 194, Pl. 6:1, 3.

${ }^{103}$ Cf. Humbsch 1998.
} 26-27. excavated in Siedlęcin (Fig. 5:1-n). The first and the second specimen came from the glass workshop located in Kolsko (it operated in the years 1763 or 1764 - after 1830). Bottles with these versions of seals are dated, respectively, to the year 1765 and the years 1765-1811. ${ }^{104}$ The third specimen was manufactured in the Karlsthal glass workshop near Szklarska Poręba (active between 1754 and 1890s), which belonged to the Preussler Family. ${ }^{105}$

Glass workshops that operated at the territory of Gdańsk Pomerania (2), were confirmed by the seals discovered in Gdańsk itself ${ }^{106}$ and in Warsaw. ${ }^{107}$ These items are bearing the imprint "DANTZIG" (Fig. 5:p) or „Neuhof” (Nowy Dwór) (Fig. 5:q). ${ }^{108}$

The inscription "HUTA SZTABIŃSKA" on the seal attached to a bottle found in Łomża is the material evidence of the functioning of another glass workshop, this time in Podlasie region. It operated in the second half of the $18^{\text {th }}$ century and the $1^{\text {st }}$ half of the $19^{\text {th }}$ century. ${ }^{109}$

\footnotetext{
${ }^{104}$ Grabny 2016, 262-263, Fig. 20-21; 271, P1. 2:9, 11.

${ }^{105}$ Grabny 2016, 263, Fig. 22; 271, Pl. 2:10.

${ }^{106}$ Krukowska 2007a, 434, Fig. 4; Szczepanowska 2013, 285.

${ }^{107}$ Blusiewicz 2013, 88-90, Pl. II:9.

${ }^{108}$ Only on the bottle found in Gdańsk, Krukowska 2016, 212 213, Fig. 4:c.

${ }^{109}$ Jurzysta 2014, 103; see also Kamieńska 1974, 94, 96, Map 5, no. 178.
} 
Among the an unidentified Polish glass workshops, there is one hiding behind the name "HUTA OLICHAWSKA" and "HUTA OLICHAWSKY" 110 (Fig. 5:r-s), which probably was located somewhere in central Poland, assuming that it operated near the place of the discovery (in Łowicz). ${ }^{111}$

Glass workshops that operated in more distant locations - most probably in Charlottenburg (currently a part of Berlin), in Bad Pyrmont in Westphalia, and in the Netherlands, as indicated by artefacts from, respectively, Gdańsk, with the inscription "H. Faselow. Charlottenburg"; 112 from Stargard, with the signs "PYR[...]ONT W[...]TER", ,[...]RMONT WATI R" and "[...]RMONTER STAHLWASSE[...]"113 (Fig. 6:ac), and from Elbląg signed "CON STANTIA WYN" 114 (Fig. 6:e-f). Another bottle, with an inscription in the Cyrillic alphabet "[...] ЕНБЕР[...] $\mathrm{b}$ "115, discovered in Łomża, most probably comes from the Russian Empire.

Other reordered specimens include symbols that most probably refer to the capacity of individual vessels, in the form of Arabic and Roman numerals and fractions (i.e. numerical signs) or letters - abbreviations or acronyms of units of capacity used in measuring liquid commodities. Producing bottles of a certain size and signing them appropriately was regulated and monitored by the state. For the Kingdom of Poland ordinances concerning the capacity of bottles were issued in the years 1819 and $1830,{ }^{116}$ while for Prussia - in $1816 .{ }^{117}$ Primarily they

${ }^{110}$ Poturalska 1999, 318-319, Fig. 1:2-3.

${ }^{111}$ That manufacture was not recorded in the inventory of glass workshops operating in Poland in the second half of the $18^{\text {th }}$ century and the first half of the $19^{\text {th }}$ century complied by Zofia Kamieńska (see Kamieńska 1974, 94-97, Map 5).

${ }^{112}$ Krukowska 2016, 213.

${ }^{113}$ Wojciechowska 2015, 186-187, 199, Fig. 9:1-2. See also Kwiatkowski 2010, 103; 108, [Fig.] 8:5 (the author incorrectly deciphered the inscription on that seal).

${ }^{114}$ Gołębiewski 1997, 196-197, Fig. 3:b-c. The author suggested that these bottles come from Constance, on the border of contemporary Germany and Switzerland. After Roy Morgan the bottles with this inscription are Dutch vessels bearing the name after Constance, wife of Governor van der Stell (Morgan 1976, 102).

115 The discussed chapter does not contain any description of the seal and it is not possible to decipher the full inscription in the circumscription (Bienia 2014, 151). Most probably it is the name of the glass workshop or the name of its owner.

116 They ordered using half-pint, pint, pint and a half, quart, three-quart bottles, etc. and indicating the "capacity of bottles with a glass stamp on the shoulder or the bottom" (Włodarczyk 2017, 145 , footnote 15 ).

${ }^{117}$ Siwiak 2007a, unpaged. The unit of measurement that was introduced at that time -1 Berliner Quart equalled to 1.145 litre, whereas 3/4 Berliner Quart - approximately 0.86 litre. In Saxony (since 1836), Bavaria (since 1868), and Mecklenburg (since 1872), the capacity of bottles was given only in litres. The signing of ready-made bottles was previously regulated by Prussian decrees, e.g. from the years 1728, 1733, 1739 (see also Mucha 1997, 118). were supposed to prevent the manufacturing of nonstandard bottles. Signs found on published specimens include, for instance: "3", "III", “3/4", "III K" or "K 3" (i.e. three half-pints; letter $K$ - from the Polish word kwarta $\left.^{\text {quart }}\right)^{118}$ - on seals discovered in Warsaw ${ }^{119}$ (Figs. 5:a, e and 7:b-c, g; other examples see Fig. 1:ef, $2: c) ; " 3 / 4 "$ " on the artefact discovered in Torun ${ }^{120}$ (Fig. 7:h); "Q" (i.e. a quart from the Latin quarta pars - the fourth part) ${ }^{121}$ - on seals discovered in Bydgoszcz, ${ }^{122}$ "1 Qua[rt]" - on the item from Krosno Odrzańskie" 123 and " $\mathrm{K}$ 4"- on finds from Warsaw; ${ }^{124}$ "K 1" and "K 2" - on bottles discovered in Brześć Kujawski, ${ }^{125}$ and in the variation "K II" and " $2 \mathrm{~K}$ " recorded in the assemblage of glass from Lowicz; ${ }^{126}$ (Fig. 5:r-s) or "1 Kw" - on find from Bąkowa Góra ${ }^{127}$ (Fig. 7:j; other examples see Fig. 1:a-d). The last five signs are interpreted as units of measurement equal to one or two half-pints. There are also known artefacts with signs " $\mathrm{G} 1 / 2$ " and "G 1 " found in Bąkowa Góra (Fig. 7:i, k), interpreted as the capacity of half a gallon and one gallon ${ }^{128}$ - the measurement used in English-speaking countries. The capacity expressed in a unit used in the Russian Empire (since 1835), including in the Congress Poland (since 1849), equal to "1/20 ВЕДРО" 129 was impressed on a bottle discovered in Łomża. ${ }^{130}$

The sign "IX" or "XIX" with raised dots in the circumference that filled the impression on the seal recorded in Łódź ${ }^{131}$ is perhaps a series number.

${ }^{118}$ According to Polish units of capacity used in measuring liquid commodities prior to the Partitions of Poland, which were still used in the $19^{\text {th }}$ century, kwarta (quart) $=0.942$ litre, and kwaterka $=0.235$ litre (Ihnatowicz 1967, 42, tab. 26).

${ }^{119}$ Baturo 2017, 218-222; other finds: Kozłowska 1994, 38, no. 102; Lipiec 2017, 142, Fig. 5:1; 198.

${ }^{120}$ Nawracki 1999, 92-93, Fig. 15:d.

${ }^{121}$ Quart (kwarta) $=1.17$ litre, is a Prussian unit of measuring liquids capacity used until 1816 (Ihnatowicz 1967, 46, Tab. 37). In the years 1817-1872 the official unit of measurement was the so-called Berliner Quart (Berlin quart) $=1.145$ litre (Ihnatowicz 1967, 47, Tab. 39).

${ }^{122}$ Siwiak 2002, 24, Fig. unnumbered, nos. 3-5; Siwiak 2003, 60.

${ }^{123}$ Dziedzic and Kałagate 2002, 77.

${ }^{124}$ Lipiec 2017, 172, Fig. 5:c-d; 199.

${ }^{125}$ Andrzejewska 1996, 129.

${ }^{126}$ Poturalska 1999, 318-319, Fig. 1:3-4.

127 Głosek 1998, 44; 74, Pl. XII:4.

${ }^{128}$ Głosek 1998, 44; 74, Pl. XII:1-2, 5. Gallon - is a unit of measurement which in England around 1835 was equal to 4.54 litres (Ihnatowicz 1967, 58, Tab. 58), whereas the the wine gallon, i.e. the old English unit of measurement equalled to 3.7852 litres (Ihnatowicz 1967, 79).

129 Wiedro (wiadro, bucket) is a Russian unit of capacity used in measuring liquid commodities equal to 12.299 litres (Ihnatowicz 1967, 49, Tab. 43).

${ }^{130}$ Bienia 2014, 151.

${ }^{131}$ Dziubek et al. 2002-2003, 368, 380, Fig. 6:5. 

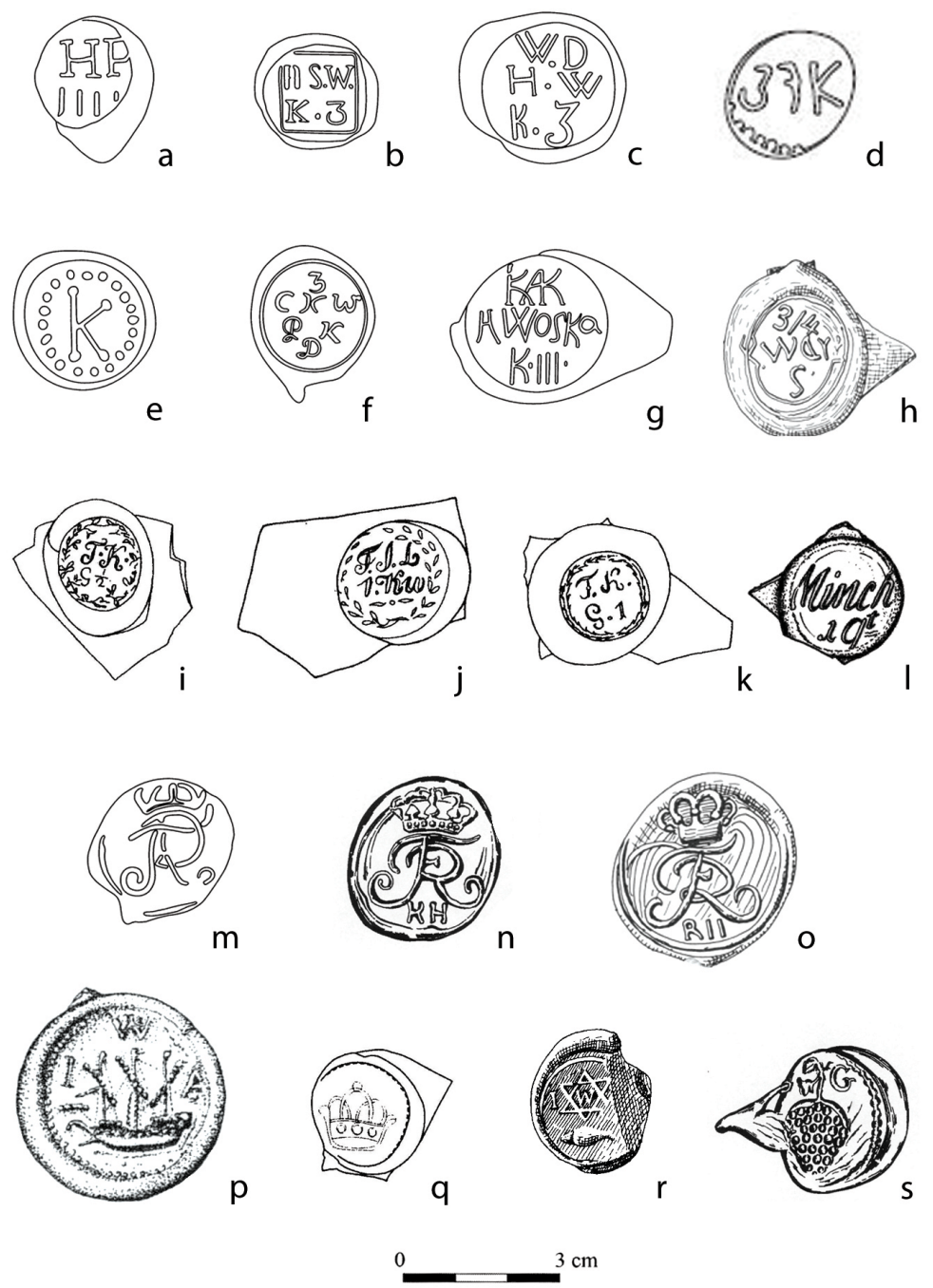

Fig. 7. Examples of glass seals with unidentified inscriptions and monograms (a- 1), with monograms in the form of stylised letters "FR" (m-o), and with iconographic symbols ( $\mathrm{p}-\mathrm{s})$ from the $17^{\text {th }}-19^{\text {th }}$ century discovered in Poland: a-g, $\mathrm{m}-$ finds from Warsaw. After Baturo 2017, 235, Pl. 5:3-4, 7-8, 10-11; 16, 24; h, o, r - finds from Toruń. After Nawracki 1999, 89, Fig. 12:b; 93, Fig. 15:d-e; i-k - finds from Bąkowa Góra. After Głosek 1998, 74, Pl. XII:2, 4-5; n, s - finds from Elbląg. After Gołębiewski 1997, 197, Fig. 3:a, g; p - find from Gdańsk. After Krukowska 2007a, 434, Fig. 6; q - find from Fordon. After Siwiak 2003, 60, Fig. 1:1.

On the territory of contemporary Poland archaeologists also discovered seals with signatures in the form of signatures made from several letters put together, which now are incomprehensible, for instance: "AB" on seal from Chełmno; ${ }^{132}$ "IDB" - from Raciążek; ${ }^{133}$ "CKW", "F.K", "PMBK", "W.D H.W"HP S(?)AR", "H.S.W", "KAK H WOSK", "WARSCH" - from Plac Zamkowy in Warsaw ${ }^{134}$ (see Fig. 7:a-g; other examples see Fig. 2:c-d); "S.F", "H R" - impressed on specimens from Łowicz; 135 "KWD(inverted)Y / S" - from

\footnotetext{
${ }^{132}$ Olczak 1991, 78-79, Fig. 5:b.

${ }^{133}$ Kajzer 1981, 163-166.

${ }^{134}$ Baturo 2017, 219, 221-223.

${ }^{135}$ Poturalska 1999, 318-319, Fig. 1:1, 4.
}

Toruń136 (Fig. 7:h); "CFD", "WPS", "H", "iG" - on artefacts from Elbląg; ${ }^{137}$ as well as "H E", "K R Q" on finds from Ostrów Tumski in Wrocław; 138 "C W" and "G" on seals from Stargard, ${ }^{139}$ "FW" - on one artefact from Szczecin, ${ }^{140}$ "HP" - from Sandomierz, ${ }^{141}$ while "HAUBAQ" on a seal from Poznań. ${ }^{142}$ Perhaps they were monograms of the owners, tenants of glass

\footnotetext{
${ }^{136}$ Nawracki 1999, 92-93, Fig.15:d.

${ }^{137}$ Gołębiewski 1997, 192.

${ }^{138}$ Siemianowska 2015, 224, Fig. 10:e, j.

${ }^{139}$ Wilgocka 2016, 228; 238, Fig. 5:16; 239, Fig. 6:4.

${ }^{140}$ Cnotliwy 2014, 279.

${ }^{141}$ Rubnikowicz 1996, 447, P1. V:14.

${ }^{142}$ Kufel 2018, 181.
} 
workshops or product distributors. ${ }^{143}$ Their exact explanation seems to be possible through further studies on written records. The recurring letter $\mathrm{H}$, which appears several times alongside other letters or words (W; R; $\mathrm{E}$; AUBA), in some cases probably is an abbreviation of the word huta (glass workshop in Polish), whereas the remaining symbols next to that letter may refer to location, for instance, like in the case of the known sign "HLO" - from the glass workshop (H[uta]) in Łochów ([LO]chow) or "H:LUTKOWSKA" (H[uta] Lutkowska) near Warsaw. Most probably other markings, which have not yet been unidentified, played a similar role, although we still do not know if they are a part of an entire name or a monogram, for instance: "ZSKOW" on the specimen discovered in Pomorzan$\mathrm{ki},{ }^{144}$ or "MINCH" - an ambiguous sign on the artefact from Stargard ${ }^{145}$ (Fig. 7:1).

Monograms in the form of stylised letters "FR" with a royal crown above them, presumably are initials of the Prussian king Frederick II the Great (reign: 17401786)..$^{146}$ They were recorded, for instance, in Elbląg, ${ }^{147}$ Toruń, ${ }^{148}$ and Warsaw ${ }^{149}$ (Fig. 7:m-o).

This group of seals is associated with another one, having a similar purpose, although artefacts from that category of finds are rarely recorded. These are stamps with individualised signs - i.e. inscriptions believed to be surnames or initials of individuals, companies, or manufacturers that ordered signed glass products (this category of finds will be hereinafter generally referred to as "trademarks"). Only a few such specimens have been identified, for instance, those discovered in Gdańsk: "I JO KEILER [...]" - a seal with the surname of a $19^{\text {th }}$-century merchant from Gdańsk, Johann Keiler, who owned a liqueur factory that operated in Gdańsk from 1814; ${ }^{150}$ and "J.J. KEILER" (Fig. 6:g), "GTA" ${ }^{151}$ In the group of finds from Stargard, there was a sign with the imprint: "BERGEMANN ER$B E N "$, i.e. the brewer from Szczecin named Bergemann

${ }^{143}$ See Gołębiewski 1997, 187; Mucha 1997, 118.

${ }^{144}$ Słomska 2013, 142.

${ }^{145}$ Wilgocka 2016, 228; 238, Fig. 5:15.

146 That sign resembles the monogram placed, for instance, on coins minted during the reign of that monarch, e.g. a pfennig from 1755, see Bucka et al. 2017, 224, 238, Fig. 28:1.

${ }^{147}$ Gołębiewski 1997, 198.

${ }_{148}$ Nawracki 1999, 92-93, Fig. 15:e.

${ }_{149}$ Baturo 2017, 219.

${ }^{150}$ Szczepanowska 2015, 310; 302, Fig. 105:10; see also Morgan 1976, 104.

${ }^{151}$ Krukowska 2016, 212-213. Their meanings were not further clarified by the author. Based on the artefact from the Wisłoujście fortress, the identification of the first sign and linking it to the operations of the Gdańsk merchant Keiler seems to be the correct explanation. and his successor (Fig. 6:h) ${ }^{152}$. Initials "FI" (or "FJ") found on another artefact probably refer to the glass merchant from the Duchy of Mecklenburg-Strelitz, who operated in the years $1840-1850 .{ }^{153}$ The inscription "CGS / 177Z" was most probably made to the order of a Stargard distiller Speichert or the innkeeper Schiersmann, who around 1772 operated his inn near the Pyrzycka gate. ${ }^{154}$ Whereas letters "FSH" were identified as an abbreviation referring to the name of a pharmacy - Fürstlisch Sächsichen Hofapotheke. That sign was placed on a vessel manufactured by the glass workshop in Friedrichsthaler. ${ }^{155}$ The product of the local alcohol distillery of vodkas and liqueurs, owned by the Kantorowicz Family (operated in the years 1823-1920), was indicated for the artefact from Poznań. In the latter case, however, the inscription was replaced with the Star of David motif. ${ }^{156}$ The same factory was linked to another specimen, which was only partly preserved and came from the same site, bearing the inscription "HARTWIG". ${ }^{157}$ The name of a liqueur distillery, which functioned in Stargard in the years 1835-1945, and belonged to Ferdinand Johann Mampe, ${ }^{158}$ is hidden behind the partially preserved inscription "SCH[UTZ d. WAARENBEZ.]", preceded by: "[12.MA]I 1894 GESETZ z.", on a seal found in Elbląg ${ }^{159}$ (Fig. 6:d). It is an example of factory trademark used from that date. Furthermore, a trademark is probably the unidentified sign impressed on the surface of the bottle discovered in Dubno: "CRUS [...] HIRS [...] BO". ${ }^{160}$

Glass seals discovered on the territory of Poland and included in publications sometimes contain other elements, such as dates. Such dates, from the period from the beginning of the $18^{\text {th }}$ century to the end of the $19^{\text {th }}$ century. These dates are mainly noted on artefacts from the western part of modern-day Poland (see

${ }^{152}$ Wilgocka 2016, 228, 239, Fig. 6:5. Information on that subject can be found, for instance, in press advertisements from the years 1820 and 1823, Humbsch 1999.

${ }^{153}$ Wilgocka 2016, 228, 238, Fig. 5:16.

154 Majewski 2017, 103-104.

${ }^{155}$ Kwiatkowski 2010, 103.

${ }^{156}$ Kufel 2018, 181.

${ }^{157}$ Kufel 2018, 182; see also Morgan 1976, 104.

${ }^{158}$ Paduch et al. 2009-2016, „Szklane pieczęcie firmy Mampe”, glass seal on the right.

${ }^{159}$ Gołębiewski 1997, 199-200, Fig. 4:i. The author suggested that was the name of a local entrepreneur - Ferdynand Schichau (1814-1896). He carried out wide ranging business operations, in particular the production of steam engines. He owned a factory of steam locomotive, a shipyard, and a ship company, see Dutkiewicz 2015.

${ }^{160}$ An undated specimen, which was not described in the publication, recorded in the form of a photograph, Garas and Karwowska 2013, 278, Fig. 9. 
Fig. 4:g, j, k, o), for instance, dates: 1712, 1764, 1772 from Stargard, referring to the year of the production of bottles or - as in the first case - possibly the year of the establishment of the pharmacy, for which they were manufactured. ${ }^{161}$ The year 1764 impressed on the seals from the Lotzen (Łośno) glass workshop; ${ }^{162} 1758$ and 1785 - appearing on seals from the Annenwalde glass workshop discovered in Szczecin; ${ }^{163}$ 1744, 1749, 1750, 1754 and 1766 - on the bottles from the Marienwalde glass workshop; ${ }^{164}$ and the year 1789 - on the specimens from Darłowo, ${ }^{165}$ Fordon and probably from Labiszyn, produced in the glass work in Lippusch, ${ }^{166}$ as well as dates 1805 and 1811 - on the artefacts discovered in Stargard, ${ }^{167}$ Elbląg ${ }^{168}$ and Fordon, ${ }^{169}$ from the Pipstock or Mehrenthin glass workshops. In the group of analysed finds the youngest date - 1894 is impressed on the above-mentioned specimen found in Elbląg (Fig. 6:d). ${ }^{170}$

Images, geometric symbols, floral and zoomorphic representations, being iconographic symbols, and constituting the main motif on the seal, were recorded only in a few individual cases. For instance, these include a ship - a three-masted vessel with lowered (folded) sails, with diagonal rigging (also referred to as Latin), which was popular in the Mediterranean, on one find from Gdańsk (Fig. 7:p); ${ }^{171}$ a schematic crown, being the symbol of the monarchical power, on a seal from Fordon (Fig. 7:q) ${ }^{172}$ an isosceles triangle on the artefact from Ostrów Tumski in Wrocław; ${ }^{173}$ the Star of David on the artefact from Poznań, ${ }^{174}$ also with an inscribed letter "W" and a fish facing left underneath it, on the specimen discovered in Torun (Fig. 7:r). ${ }^{175}$ The hexagram and the fish are common symbols characteristic for Judaism, which were placed, e.g. on Jewish ritual vessels. ${ }^{176}$ It is assumed that

${ }^{161}$ Kwiatkowski 2010, 103-104. Another item from Stargard with date probably 1772, see Majewski 2017, 103-104.

${ }^{162}$ Burdziej et al. 2014, 380, Fig. 11:4; Szeremeta 2018, 390, 392, Fig. 5:4.

${ }^{163}$ Cnotliwy 2014, 278.

${ }^{164}$ Stolpiak and Świercz 1997, 44-45; Woźny 2001, 246, Fig. 1:5; 249; Burdziej et al. 2013, 349; Burdziej et al. 2014, 389, Fig. 19:7; Bucka et al. 2015, 488, 491, Fig. 17:3; Bucka et al. 2017, 224, 238, Fig. 28:2.

${ }^{165}$ Kuczkowski 2016, 162, no. 1.3 .

${ }^{166}$ Siwiak 2007a, unpaged.

${ }^{167}$ Burdziej et al. 2013, 354.

${ }^{168}$ Gołębiewski 1997, 195.

${ }^{169}$ Woźny 2001, 247, Fig. 2:2; 250-251.

${ }^{170}$ Gołębiewski 1997, 199-200, Fig. 4:i.

${ }^{171}$ Krukowska 2007a, 434, Fig. 6.

${ }^{172}$ Siwiak 2003, 60-61, Fig. 1:1.

${ }^{173}$ Siemianowska 2015, 224, Fig. 10:h; 228, Fig. 14:e.

${ }^{174}$ Kufel 2018, 181.

${ }^{175}$ Nawracki 1999, 88-89, Fig. 12:b.

${ }^{176}$ See Piątkowska and Żebrowski 2008-2020; Sieramska 2008-2020. they were impressed on glass products by Jewish manufacturers and/or intended for Jewish customers. However, it is also possible that simultaneously this also served as a confirmation that the liquid stored in such a container was kosher. ${ }^{177}$

Other pictograms include a bunch of grapes on the seal from Elbląg (Fig. 7:s) ${ }^{178}$ - a symbol of abundance, a popular motif used at that time for decoration of numerous goods (e.g. modern stove tiles); and the representation of an eagle with spread wings - the emblem of the Kingdom of Prussia, known for instance from seals discovered in Bydgoszcz ${ }^{179}$ and Gniewkowo. ${ }^{180}$ However, signs in the form of a six-pointed star, grapes, and the Prussian eagle are usually only graphic additions to inscriptions. $^{181}$

Published glass seals from the territory of Poland sporadically have heraldic signs on them, in the form of standalone marks or grouped with inscriptions. We know only a few such signs, including several from Stargard, of which one remains unidentified, ${ }^{182}$ and three are coats of arms of the Principality of Waldeck and Pyrmont ( 2 specimens) and the Pyrmont region (1 specimen). The latter were accompanied by the name of spring water - Pyrmont Water and Pyrmonter Stahlwasser (Fig. 6:a-b), ${ }^{183}$ transported in bottles bearing the above-mentioned signs. At the same time, a glass seal discovered in Elbląg shows the view of the Mill Gate (Mühlentor in German) in Stargard, one of the four gates of that medieval town and important local monument (Fig. 6:d). ${ }^{184}$

Among the recorded finds, a relatively high percentage and territorial range characterises vessels with seals bearing the name "London" (Fig. 8). According to the division created by A. Gołębiewski, they can also be classified as descriptive signs. They represent various forms - there are specimens with inscriptions in the full form ("LONDON"), as well as with abbreviations or misspelled, but always written in capital letters. Usually, the seal contains a crown above

${ }^{177}$ Another seal that may be associated with Jewish symbols can be the artefact with the inscription in capital letters "ARIEL", which is the only element placed on the seal attached to the bottle discovered in Stargard (Burdziej et al. 2013, 352, 379, Fig. 32). Ariel is a Hebrew man's name or a poetic name for Jerusalem (Żebrowski 2008-2020).

${ }^{178}$ Gołębiewski 1997, 197-198, Fig. 3:a.

${ }^{179}$ Siwiak 2007a, Fig. 7:4, 6, 8, 12.

${ }^{180}$ Sulkowska-Tuszyńska 2018, 123; 195, Fig. 93:c.

${ }^{181}$ See examples in Gołębiewski 1997.

${ }^{182}$ Burdziej et al. 2013, 354, 384, Fig. 39. That coat of arms was not identified in the source publication. The author also was not able to identify it on the basis of the printed photograph.

${ }^{183}$ Wojciechowska 2015, 186-187, 199, Fig. 9:1-2. For more information on the form of such inscriptions see page 11 .

${ }^{184}$ See Paduch et al. 2009-2016. 


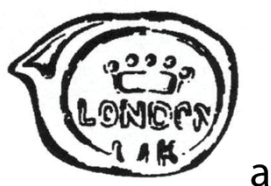

a

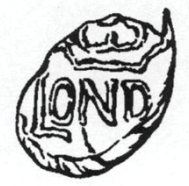

e

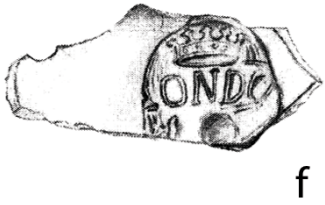

$\mathrm{f}$

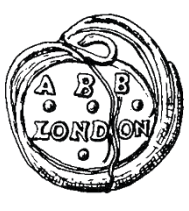

i
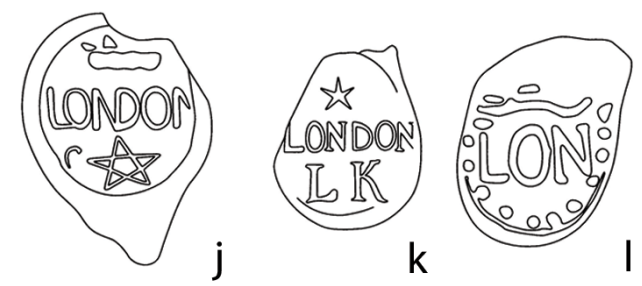

g
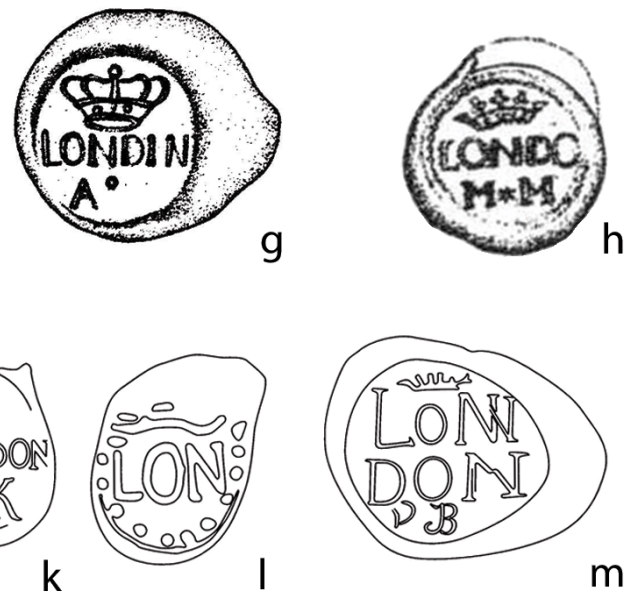

$\mathrm{m}$
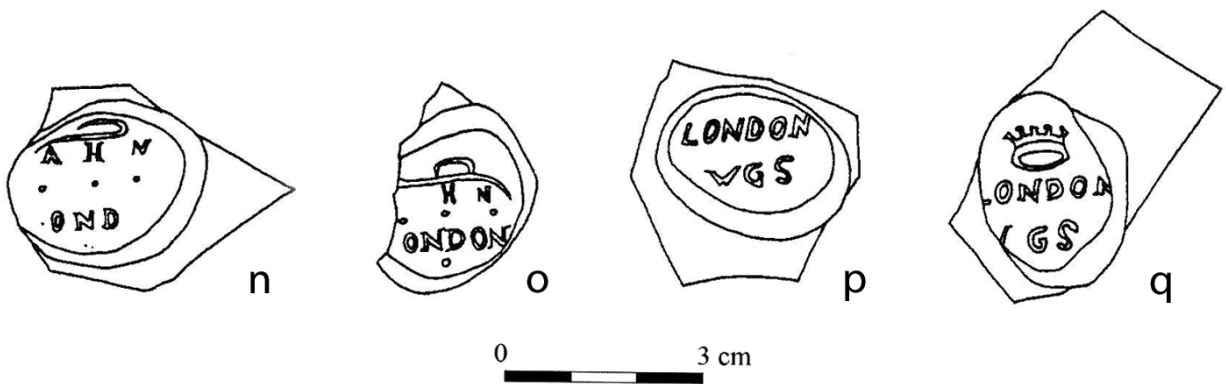

Fig. 8. Examples of glass seals with signs with the word "London" in different spelling variations from the $17^{\text {th }}-19^{\text {th }}$ century discovered in Poland: a-e - finds from Elbląg. After Gołębiewski 1997, 189, Fig. 1:a-b, e-f, h; f - find from Poznań. After Antowska-Gorączniak 2012, 194, Pl. 6:2; g-h - finds from Gdańsk. After Krukowska 2007a, 434, Fig. 5; Krukowska 2016, 213, Fig. 4:d; i - find from Toruń. After Nawracki 1999, 93, Fig. 15:a; j-m - finds from Warsaw. After Baturo 2017, 235, Pl. 5:12-13, 26-27; n-q - finds from Fordon. After Woźny 2001, 246, Fig. 1:1-4.

the text and a five-pointed star below it (Fig. 8:b,j), with various additional monograms (e.g. AC, AHB, AHN, CFD, DG, H, HN, IDB, iG, MM, PG, RG, WPS), although in the case of some sites archaeologists recorded also other forms. For instance, we know the following versions: "LONDON", "[L]ONDEN", "LON DON" on artefacts from Warsaw (Fig. 8:j-m); 185 "LONDEN", "LOND", "ONDO", "ONDN" discovered in Elbląg (Fig. 8:a-e); 186 "LONDON", "LONDN", "LONDEN" on specimens from Chojnice, 187 "LONDIN" - in Gdańsk (Fig. 8:g), 188 "LONDON", “ONDEN" on seals

${ }^{185}$ Baturo 2017, 220-223; name „LONDEN”- also on the seal from Warsaw town hall, Blusiewicz 2013, 88-90, Pl. II:8.

${ }^{186}$ Gołębiewski 1997, 188-190, Fig. 1.

${ }^{187}$ Garas and Trzciński 2010, 38.

${ }^{188}$ Krukowska 2016, 213, Fig. 4:d. discovered in Toruń (Fig. 8:i); 189 "ONDO", "ONDE" - in Poznań (Fig. 8:f); 190 "OND" and "ONDON" - on seals from Fordon (Fig. 8:n-q) ${ }^{191}$ The name spelled as "LONDO" impressed on artefacts from excavations in Średnia Huta, ${ }^{192}$ Gdańsk (Fig. 8:h), ${ }^{193}$ Poznań, ${ }^{194}$ Radom, ${ }^{195}$ and Witów, ${ }^{196}$ as well as the item found in Chełmno. ${ }^{197}$ The full mark "LONDON" is impressed

${ }^{189}$ Rubnikowicz 1989b, 77, Pl. II:1; Nawracki 1999, 92-93, Fig. 15:a-b.

${ }^{190}$ Kufel 2018, 181.

${ }^{191}$ Woźny 2001, 246, Fig. 1:1, 3; 248.

${ }_{192}$ Rubnikowicz 1989a, 52-53, Pl. I:7-8.

${ }^{193}$ Krukowska 2007b, 36-37, Fig. 1; Szczepanowska 2013, 285.

${ }^{194}$ Antowska-Gorączniak 2012, 151.

${ }^{195}$ Lechowicz 2012, 124, [Fig.] 108.

${ }^{196}$ Andrzejewski and Kajzer 2001, 334.

${ }^{197}$ Olczak 1991, 78-79, Fig. 5:a. 
also on finds from Biskupice, ${ }^{198}$ Dubno, ${ }^{199}$ Fordon, ${ }^{200}$ Gdańsk, ${ }^{201}$ Poznań, ${ }^{202}$ Puck, ${ }^{203}$ and Radoszyce. ${ }^{204}$

The provenance and function of those bottles have been discussed many times in Polish publications. It is assumed that they were products imported from England together with their contents (mostly beer) or without it, or they were locally produced goods. The latter interpretation seems to be equally probable, as evidenced by the artefacts containing typos in the word London. In such cases, signs on the seals were supposed to increase the commercial value of the labelled goods ${ }^{205}$ emphasizing the provenance of the foreign beverage imported in barrels and sold in bottles manufactured in the country of the importer. This option (Polish origin of the glass) was already confirmed as a result of physicochemical analysis of such finds from the area of the post-medieval glass workshop in Średnia Huta. ${ }^{206}$ We could also look at this practice from another point of view - possibly as an indented falsification of the country of origin of the vessel and the liquid it contained. How such products were distributed is also interesting. Currently, as indicated by the above-mentioned examples, we know at least a dozen or so towns and villages, in which such finds, have been recorded. ${ }^{207}$ Generally, they are located in different parts of Poland - from Radom to Puck, from Dubno to Poznan. A concentration of such finds can be observed in the central, longitudinal part of the country, from the south - Lesser Poland, through Mazovia and Kuyavia to the north - to Gdańsk Pomerania. Perhaps this phenomenon is associated with the ways of distribution (the Vistula route) or the cumulation of domestic production centres - both explanations are probable.

An interesting problem, which so far has been discussed only sporadically in Polish archaeological publications, is the use of glass bottles with seals for the

${ }^{198}$ Ruszkowska 2007, 148, Fig. 3:6, 149-150.

${ }^{199}$ Garas and Karwowska 2013, 266.

${ }^{200}$ Woźny 2001, 246, Fig. 1:2, 4; 248.

${ }^{201}$ Szczepanowska 2013, 285; Szczepanowska 2015, 304, Fig. 106:3; 310

${ }^{202}$ Wawrzyniak 2000, 74, Fig. 17.

${ }^{203}$ Starski 2015, 160-163, Fig. 141:1.

${ }^{204}$ Kajzer 1988, 143.

${ }^{205}$ See Gołębiewski 1997, 191. For other interpretations see e.g. Woźny 2001, 248-249; Szczepanowska 2013, 285-296; Baturo and Kasprzak 2018d, 34, footnote 1.

${ }^{206}$ Rubnikowicz 1989a, 61-62.

${ }^{207}$ In his work from 1981, Leszek Kajzer recorded in Poland only five sites with these types of finds: Frombork (currently Warmińsko-Mazurskie Voivodeship), Piotrków Trybunalski (currently Łódzkie Voivodeship), Raciążek (Kujawsko-Pomorskie Voivodeship), Ujazd (Świętokrzyskie Voivodeship), Zakrzew (Łódzkie Voivodeship), Kajzer 1981, 171, Fig. 7. Since that time that number has greatly increased. distribution of mineral water in the late modern period. ${ }^{208}$ Water from popular springs, which were believed to have healing properties, was distributed in branded containers since the end of the $17^{\text {th }}$ century. In such cases, seals also confirmed the origin and the reputation of the beverage stored in the bottles. Four finds from Stargard give us the basis to state that glass containers with seals were used to import spring water from Bad Pyrmont in Lower Saxony ${ }^{209}$ and from Szczawno Zdrój in $\operatorname{Silesia}^{210}$ (Fig. 6:a-c).

Archaeologists sometimes also record glass seals only in the form of blank discs attached to walls of glass vessels but without any imprints. Such finds, for instance, were discovered in Bąkowa Góra; ${ }^{211}$ in Elbląg: ${ }^{212}$ in Fordon; ${ }^{213}$ in Gdańsk; ${ }^{214}$ in Łabiszyn; ${ }^{215}$ in Toruń; ${ }^{216}$ and in Warsaw, ${ }^{217}$ as well as in Wilanów. ${ }^{218}$ Usually archaeologists record several such finds on a given site, but their percentage compared with the total number of glass seals is rather high, ranging between $13.5 \%$ and $37.5 \%$. The exception is the latter find - a single specimen discovered at that archaeological site. We also know artefacts with illegible or fuzzy signs, recorded, for instance, in Trzemeszno (several specimens), ${ }^{219}$ Warsaw (2 items) ${ }^{220}$ or Chełmno (1 item) ${ }^{221}$ (other examples see Fig. 2:a-b). These are, however, atypical specimens, the genesis of which has no easy explanation. It is possible that

\footnotetext{
${ }^{208}$ These matters were discussed by Iwona Wojciechowska in her paper on the consumption of mineral waters in modern Stargard (Wojciechowska 2015). For information on the potential of such studies and the possibility of identifying finds see, for instance, Brinkmann 2019; Brinkmann 2020.

${ }^{209}$ Wojciechowska 2015, 186-187, 199, Fig. 9:1-2. Those are seals with coats of arms of the Principality of Waldeck and Pyrmont ( 2 specimens) and the Pyrmont region (1 specimen).

${ }^{210}$ Wojciechowska 2015, 187-188, 199, Fig. 9:3. It is one specimen with the inscription: "SALZBRUN" and "No 1". A similar find comes from, e.g. Stralsund (see Brinkmann 2020, 8).

${ }^{211} 3$ specimens for the total number of 8 finds, Głosek 1998, 44; 73, Pl. XI:11, 12; 108, Pl. XLIV:1, 2.

${ }^{212} 8$ specimens in the total number of 37 glass vessels discovered at that site, Gołębiewski 1997, 188.

2131 find in the total number of 3 seals found at the site, Siwiak 2003, 60, Fig. 1:3.

${ }^{214} 1$ find in the total number of 5 discovered vessels, Szczepanowska 2013, 285.

${ }^{215} 1$ find in the total number of 5 finds, Siwiak 2007a, unpaged.

2162 items in the total number of 7 finds, Nawracki 1999, 8889, Fig. 12:c; 92-93, Fig. 15:c

2177 items recorded by K. Baturo, in the total number of 59 seals from Plac Zamkowy (Baturo 2017, 217).

${ }^{218}$ The only find at that site, Andrzejewska et al. 2002-2003,

${ }^{219}$ Wiewióra 2000, 201.

${ }^{220}$ Baturo 2017, 217.

${ }^{221}$ Olczak 2001, 78-79.
} 300. 
they are examples of flawed seals, the result of an oversight or mistakes made during the production process, for instance as a result of a shoddy application of the glass disc and impressing the stamp in still too molten glass. Perhaps they are the evidence of abandoned orders placed for signed vessels, which despite the withdrawal of the specific commission were sold to another customer. We cannot rule out, however, that it was a deliberate action aimed at hiding the scale of production from the tax authorities, or at least or understating it. Smooth surfaces of glass discs may also be a secondary effect, a result of removing (grinding down) the existing imprint. ${ }^{222}$

\section{Conclusions}

Based on the literature concerning this subject and archaeological sources, it is possible to state that finds from the territory of Poland correspond with the general tendencies in terms of the quality, form, and function of this type of artefacts described by foreign scholars, whereas their specific feature (as far as it was possible to establish on the basis of published materials) is the more slender shape of vessels with seals - a greater proportion of cylindrical bottles than squat ones (of the shaft and globe, onion bottle and mallet bottle types). This is associated with the chronology of Polish finds, which are primarily vessels from the $18^{\text {th }}$ and $19^{\text {th }}$ centuries, when the slenderer forms gradually became the most popular type of manufactured glass bottles. The square-bodied bottles kept in cases (case bottles) more often are containers with seals bearing the name "London". This results from the fact that their large part constituted goods imported from England, and their domestic imitations repeated the form of the original bottles. Bottles with the name of the English capital city with the correct spelling or in a modified (also misspelled) are discovered relatively often in different parts of Poland. Their use may be seen as a deliberate marketing practice at that time. Placing a word or expression directly related to England on the seal suggested to the customers that the product was an original import from that country, even if it actually had a domestic or different provenance (for example Dutch).

Artefacts from the territory of contemporary Poland are characterised by a limited and schematic set of signs placed on the seals, and the quality of imprints is usually not very good. This is manifested through rare occurrence of dates (just on several specimens from Bierzwnik, Darłowo, Elbląg, Łomża, Pipstock, Stargard and Szczecin,), full surnames (two identified finds from Gdańsk associated with the merchant named

${ }^{222}$ See Gołębiewski 1997, 199; Mucha 1997, 118; Siwiak 2003, 61; Siwiak 2007a, unpaged.
Johann Keiler and one with the owner of the Szczecin brewery Bergemann), and complete names of glass workshops (among other things, Piekarska, Olichawska, Sztabinska, Glas Fabrik Clementienhof). The latter are usually identified based on place names written on seals - locations of the glasshouses (Bernsee - Breń, Blendow - Błędów, Dantzig - Gdańsk, Lippusch - Lipusz, Lotzen - Łośno, Marienwalde - Bierzwnik, Racado[w] - Racendów, etc.). Seals bearing only emblems: a ship, crown, triangle, the Star of David, a bunch of grapes, eagle, as well as coats of arms are rare. The majority of the discovered heraldic stamps are related with containers for spring water. Only some of the Polish finds can probably be considered as products made to order of definite breweries, liqueur factories or alcohol distilleries (with inscriptions "BERGEMANN ERBEN", "CGS", "HARTWIG", "I JO KEILER", “J.J. KEILER", “GESETZ z. SCH[UTZ d. WAARENBEZ.]”).

The largest group comprises seals with inscriptions that are probably abbreviations or initials, which today are impossible to decipher, but - as we may assume were usually trademarks.

This can be attributed to the still limited knowledge about manufacturers and buyers of modern bottles in Poland, primarily due to the insufficient recognition of written records. The exemptions are already published results on studies on glass workshops and finds of glass seals from western part of Poland as well as the recently carried out and disseminated research concerning such workshops and finds from Mazovia. For this reason, in the case of many artefacts from territory of Poland we are usually unable to establish the cause and circumstances associated with placing orders for vessels stamped with specific seals. Furthermore, there is no evidence of an occasional production of signed wares similar to those recorded abroad. ${ }^{223}$ Also because of the small number of finds, so far it has not been possible to undertake other analyses on their basis, including those concerning ownership aspects (changing leases of glass workshops or commercial counterparts). That problem will persist until we see progress in studies on various types of historical sources and issues concerning the history of Polish glass making and use of glass vessels, and in particular in relation to other regions of Poland although the identification of people and places hidden behind enigmatic signs may still not be possible.

In my opinion, the greatest potential lies in the research into the range of products manufactured in the so-called forest glass works, namely main producers of storage bottles, and orders for glass containers that were placed with them. Furthermore, another very important

${ }^{223}$ E.g. associated with private important occasions or events, see Morgan 1976, 11; Jeffries and Major 2015, 151. 
research topic may be details of commercial correspondence from the $17^{\text {th }}-19^{\text {th }}$ centuries regarding the organisation and supply or manors, purchasing beverages and ways of storing them in such estates, and the functioning of breweries, wineries, distilleries, and inns, as well as merchants trading in alcoholic beverages or spring water. Studies concentrating on the history of individual glass workshops and enterprises associated with this sector of economy may also provide valuable data on this subject. Such information may give us a better idea about the scale of production of the analysed wares, conditions, and places in which purchases were made, their frequency, quantities, and costs.

Furthermore, glass seals, particularly identified seals with proven chronology, can be good sources for archaeological dating, and thus help us with the analysis of stratigraphy and establishing the time of use of other finds from the same assemblages or deposits. Additionally, as demonstrated by the above-mentioned findings, they can be very good sources for studying selected aspects of the history of glassmaking in Poland, being the evidence of the functioning of individual glass workshops - particularly those less known - and the assortment of their products.

Without a doubt, Polish publications released to date provide valuable material for comparative studies, increasing our knowledge about types of marks that were used, their territorial diversification, and chronology, and observations compiled by me in this paper will hopefully become a starting point for further detailed analyses.

\section{Bibliography}

Andrzejewska A. 1996. Szkło naczyniowe z klasztoru OO. Dominikanów w Brześciu Kujawskim, województwo włocławskie. "Acta Universitatis Lodziensis. Folia Archaeologica" 20, 123-153.

Andrzejewska A., Andrzejewski A., Błaszczyk K., Grabarczyk T., Pietrzak J. 2002-2003. Badania archeologiczne osad wielokulturowych w Warszawie-Wilanowie. "Lódzkie Sprawozdania Archeologiczne" 8, 291-311.

Andrzejewski A., Kajzer L. 2001. Sprawozdanie z badań archeologiczno-architektonicznych zespolu klasztornego w Witowie koło Piotrkowa Trybunalskiego, przeprowadzonych w 2001 r. "Lódzkie Sprawozdania Archeologiczne" 7, 325-342.

Antowska-Gorączniak O. 2012. Późnośredniowieczne i nowożytne szkło z badań na stanowisku przy ul. Posadzego 5 na Ostrowie Tumskim w Poznaniu. In: H. Kóčka-Krenz (ed.), Poznań we wczesnym średniowieczu 7. Poznań, 147-201.

Baturo K. 2017. 16. Szklane naczynia zasobowe z badań prowadzonych na terenie placu Zamkowego. In: Z. Polak, K. Meyza (eds.), Między miastem a dworem. Badania archeologiczne placu Zamkowego w Warszawie w latach 1977-1983. Część 2. Archeologia Dawnej Warszawy 4. Warszawa, 201-235.

Baturo K., Kasprzak A. J. 2018a. Mazowieckie huty leśne szkła gospodarczego. Trębaczew - Huta Trębaczewska (1819-1829) (woj. tódzkie, pow. rawski). "Szkło i Ceramika" 3, 30-33.

Baturo K., Kasprzak A. J. 2018b. Mazowieckie huty leśne szkta gospodarczego. Btędów - Huta Btędowska (18011806/1807), woj. mazowieckie, pow. grójecki. "Szkło i Ceramika" 4, 30-32.

Baturo K., Kasprzak A. J. 2018c. Mazowieckie huty leśne szkta gospodarczego. Lutkówka - Huta Lutkowska (1838-1851/1852), woj. mazowieckie, pow. żyrardowski. "Szkło i Ceramika" 5, 36-39.

Baturo K., Kasprzak A. J. 2018d. Mazowieckie huty leśne szkła gospodarczego. Stanisławów - Huta Stanisławowska (I huta: 1796-1801/1803, II huta: 1805-1806?). "Szkło i Ceramika" 6, 34-37.

Baturo K., Kasprzak A. J. 2019a. Mazowieckie huty leśne szkła gospodarczego. Świnice - Huta Świnicka (18291838), woj. mazowieckie, pow. żyrardowski. "Szkło i Ceramika" 3, 26-29.

Baturo K., Kasprzak A. J. 2019b. Mazowieckie huty leśne szkła gospodarczego. Wałowice-Huta Wałowska (18301839), woj. łódzkie, pow. rawski. "Szkło i Ceramika" 4, 38-40.

Baturo K., Kasprzak A. J. 2019c. Mazowieckie huty leśne szkła gospodarczego. Jeżewice - Huta Tartak (19351836) = Huta Jeżewska (1836-1840), woj. mazowieckie, pow. grójecki. "Szkło i Ceramika" 5, 28-31.

Bienia M. 2014. Wykopaliska na Placu Kościuszki 3. In: Archeologia Łomży. Nowodworce, 130-151.

Bis M. 2017. Nowożytne naczynia szklane znalezione w Warszawie - możliwości i ograniczenia badań. "Kwartalnik Historii Kultury Materialnej” 65(3), 370-396.

Bis M. 2020a. Zarys stanu i problematyki polskich badań nad naczyniami szklanymi z XIV-XVIII wieku w latach 1987-2018 / A Summary of the State of the Polish Research into Glass Vessels from the $14^{\text {th }}-18^{\text {th }}$ Centuries Carried out in the Years 1987-1918 and the Outline of Key Research Problems. "Archeologia Polski" 65, 263-322. DOI: 10.23858/APol65.2020.007. 
Bis M. 2020b. Opracowanie wyników analiz metoda EPMA fragmentów naczyń szklanych pochodzacych z końca XVIII i początków XIX w. pozyskanych w trakcie badań w patacu Pod Blacha. Warszawa. Typescript in the Archive of Archaeological Department of the Royal Castle - Museum in Warsaw.

Blusiewicz K. 2013. Wyniki badań archeologicznych pótnocnej pierzei placu Teatralnego prowadzonych w latach 1995-1997. In: W. Pela (ed.), Badania archeologiczno-architektoniczne pótnocnej pierzei placu Teatralnego w Warszawie w latach 1995-1997. Archeologia Dawnej Warszawy 3. Warszawa, 73-133.

Borkowski J., Kuczkowski A. 2011. Cussalyn - Cößlin - Koszlin. Źródta archeologiczne do dziejów miasta. Koszlińskie Zeszyty Muzealne. Seria B-VIII: Archeologia 1. Koszalin.

Bossche den van W. 2001. Antique Glass Bottles. Their History and Evolution (1500-1850). Second edition. Woodbridge.

Brinkmann B. 2019. Glas- oder Steinzeuglaschen? Zum Mineralwasserverstandt der Brunnen in Godelheim und Driburg im 18. Jahrhundert. Mülheim an der Ruhr. www.academia.edu. Available on-line 17.09.2020.

Brinkmann B. 2020. Steinzeugflaschen auch für den Verstand des Heilwassers aus dem schlesischen Bad Salzbrunn (Szczawno-Zdrój). - Wo sind sie geblieben? Mülheim an der Ruhr. www.academia.edu. Available on-line 17.09.2020.

Bucka K., Burdziej M., Janowski A., Majewski M., Stań K., Szeremeta M., Wojciechowska I. 2015. Odkrycia i badania archeologiczne. "Stargardia. Rocznik Muzeum Archeologiczno-Historycznego w Stargardzie poświęcony przeszłości i kulturze Pomorza oraz innych ziem bałtyckich" 10 (2014), 463-510.

Bucka K., Janowski A., Majewski M., Stań K., Szeremeta M., Śnieżko G., Wojciechowska I. 2017. Odkrycia i badania archeologiczne. "Stargardia. Rocznik Muzeum Archeologiczno-Historycznego w Stargardzie poświęcony przeszłości i kulturze Pomorza oraz innych ziem bałtyckich” 12 (2016), 195-240.

Burdziej M., Janowski A., Kozłowska D., Kwiatkowski K., Majewski M., Matuszewska A., Stań K., Szydłowski M., Uciechowska-Gawron A. 2013. Odkrycia i badania archeologiczne. "Stargardia. Rocznik Muzeum Archeologiczno-Historycznego w Stargardzie poświęcony przeszłości i kulturze Pomorza oraz innych ziem bałtyckich" 7 (2011-2012), 333-419.

Burdziej M., Janowski A., Majewski M., Sil B., Stań K., Szeremeta M., Wojciechowska I. 2015. Odkrycia i badania archeologiczne. "Stargardia. Rocznik Muzeum Archeologiczno-Historycznego w Stargardzie poświęcony przeszłości i kulturze Pomorza oraz innych ziem bałtyckich" 9 (2014), 365-415.

Burdziej M., Sil M., Stań K., Szeremeta M. 2014. Odkrycia i badania archeologiczne. "Stargardia. Rocznik Muzeum Archeologiczno-Historycznego w Stargardzie poświęcony przeszłości i kulturze Pomorza oraz innych ziem bałtyckich" 8 (2013), 267-297.

Cnotliwy E. 2014. Archeologia Zamku Ksiażat Pomorskich w Szczecinie. Szczecin.

Cnotliwy E., Nawrolski T., Rogosz R. 1972. Wyniki badań archeologicznych w piwnicach Zamku Ksiązat Pomorskich w Szczecinie. "Materiały Zachodniopomorskie" 18, 159-233.

Dumbrell R. 1983. Understanding Antique Wine Bottles. Woodbridge.

Dutkiewicz H. 2015. Schichau, Ferdinand Gottlob. In: Elblaski Stownik Biograficzny, http://historia.bibliotekaelblaska.pl/biogram/schichau-ferdinand-gottlob-1814-1896-401. Available on-line 21.09.2020.

Dziedzic P., Kałagate S. 2002. Badania archeologiczne na zamku piastowskim w Krośnie Odrzańskim (sezon 1998). "Archeologia Środkowego Nadodrza" 2, 65-186.

Dziubek E., Lewandowski M., Zawilski P. 2002-2003. Wyniki badań archeologicznych przeprowadzonych w obrębie ulic Nowomiejskiej i Zgierskiej w Lodzi. "Lódzkie Sprawozdania Archeologiczne" 8, 361-380.

Friese G., Friese K. 1992. Glashütten in Brandenburg. Die Geschichte der Glashütten vom 16. bis zum 20. Jahrhundert mit einem Katalog ihrer Marken und 16. Farbtafeln. Heimatkundliche Beiträge 1. Eberswalde.

Friese K. 1993. Glasmarkenfunde im Kloster Chorin. "Der Glasfreund. Zeitschrift für altes und neues Glas" 1, 4-7.

Friese K. 1995. Weitere Tonstempel der Glashütte Chorin. "Der Glasfreund. Zeitschrift für altes und neues Glas" $5,20-21$.

Gajewska M., Kruppé J. 1973. Rzut oka na dotychczasowe wyniki badań archeologicznych we Fromborku. "Kwartalnik Historii Kultury Materialnej” 21(4), 617-631.

Garas M., Karwowska H. 2013. Wyroby szklane. In: H. Karwowska, A. Andrzejewski (eds.), Założenie rezydencjonalne Sapiehów w Dubnie. Białystok, 257-286.

Garas M., Trzciński Ł. 2010. Badania archeologiczne na dziedzińcu Kolegium Jezuickiego w Chojnicach. "Zeszyty Chojnickie" 25, 11-44.

Głosek M. 1998. Dwór murowany w Bąkowej Górze. Acta Archaeologica Lodziensia 42. Łódź. 
Gołębiewski A. 1997. Znaki na nowożytnych butelkach szklanych ze Starego Miasta w Elblagu. In: J. Olczak, A. Sosnowska (eds.), Studia z archeologii, historii i geografii historycznej. Archaeologia Historica Polona 6. Toruń, 183-205.

Grabny B. 2016. Szkło naczyniowe i szkło okienne. In: P. Nocuń (ed.), Wieża książęca w Siedlęcinie w świetle dotychczasowych badań. Podsumowanie na 700-lecie budowy obiektu. Siedlęcin, Pękowice, Kraków, 241-276.

Humbsch K. 1998. Kolzig, Wojewod. Zielona Góra. "Der Glasfreund. Zeitschrift für altes und neues Glas" 10, 26-27.

Humbsch 1999. BERGEMANN - das Stettiner Doppelbier. "Der Glasfreund. Zeitschrift für altes und neues Glas" $14,9$.

Humbsch K. 2001. Glasmarken der beiden Grossherzogtuemer Mecklenburg-Schwerin und Mecklenburg-Sterlitz. Neusterlitz.

Humbsch K. 2002. Alte Glashütten in Polen. Studien zur Produktionsgeschichte und den Markungen unter besonderer Berücksichtigung Pommerns, Schlesiens und Ostbrandenburgs. Neusterlitz.

Humbsch K. 2006. Das Glasmarken - ABC. Gifhorn.

Ihnatowicz I. 1967. Vademecum do badań nad historia XIX i XX wieku 1. Warszawa.

Jeffries N., Major N. 2015. Mid 17th- and 19th-century English Wine Bottles with Seals in London's Archaeological Collections. „Post-Medieval Archaeology” 49(1), 131-155.

Jurzysta E. 2014. Kamieniczka w południowej pierzei Starego Rynku. In: Archeologia Łomży. Nowodworce, 92-103.

Kajzer L. 1981. W sprawie importu piwa angielskiego do Polski w XVIII w. "Kwartalnik Historii Kultury Materialnej" 29(2), 163-176.

Kajzer L. 1988. Wstępna informacja o materiałach archeologicznych z zamku w Radoszycach. "Acta Uniersitatis Lodziensis. Folia Archaeologica" 9, 137-147.

Kamieńska Z. 1974. Produkcja szkła od pot. XVII do pot. XIX w. In: Z. Kamieńska (ed.), Polskie szkło do połowy 19 wieku, Wrocław, 83-116.

Koch J. 1997. Pyrmonter Siegel im Wandel der Zeiten. "Der Glasfreund. Zeitschrift für altes und neues Glas" 8, 27-29.

Kozłowska R. 1994. Szkło. In: Materiały do wystawy „,Rzeczy codzienne z wykopalisk zamkowych i staromiejskich”. Źródła archeologiczne do dziejów Zamku Królewskiego oraz Starej i Nowej Warszawy 1. Warszawa.

Krukowska O. 2007a. Stemple na naczyniach szklanych z Gdańska - nowe znaleziska. In: G. Nawrolska (ed.), XV Sesja Pomorzoznawcza. Materiaty z konferencji 30 listopada-02 grudnia 2005. Elbląg, 431-436.

Krukowska O. 2007b. Zabytki szklane ze stanowiska 5 w Gdańsku-Hala Targowa. In: H. Paner (ed.), Archeologia Gdańska 3. Gdańsk, 35-46.

Krukowska O. 2016. Przedmioty szklane z badań archeologicznych w Zespole Przedbramia ul. Dlugiej w Gdańsku. In: A. Pudło (ed.), Zespót Przedbramia ul. Dlugiej w Gdańsku. Studium archeologiczne. Gdańsk, 209-220.

Kuczkowski A. 2016. Wyposażenie ruchome kamienicy dartowskiej. Studium archeologiczne na przykładzie parceli przy ul. Ratuszowej (d. Kalendstrasse 7). "Koszalińskie Zeszyty Muzealne. Archeologia" 37, 107-181.

Kufel R. 2018. Wyroby szklane. In: P. Pawlak (ed.), Średniowieczny system obronny miasta Poznania. Fragmenty odcinka pótnocnego. Wyniki badań archeologicznych. Poznań, 175-241.

Kwiatkowski K. 2010. Nowożytna latryna na dawnej parceli 32 przy ulicy Kazimierza Wielkiego w obrębie kwartału IX w Stargardzie. Wyniki prac archeologicznych. „Zachodniopomorskie Wiadomości Konserwatorskie” 4, 99-108.

Lechowicz Z. 2012. Zamek w Radomiu. Archeologia i architektura. Badania i interpretacje. Radom.

Lipiec A. 2017. Zabytki szklane pozyskane w trakcie badań zespołu kamienic na rogu ulicy Traugutta i Placu Matachowskiego $w$ Warszawie. In: W. Borkowski (ed.), Badania archeologiczne dziedzińca Arsenału Królewskiego oraz zespotu Kamienicy Raczyńskich w Warszawie. 2: Badania archeologiczne zespotu Kamienicy Raczyńskich w Warszawie. Warszawskie Materiały Archeologiczne 14. Warszawa, 169-196.

Majewski M. 2012. IV. Przedmioty szklane. In: K. Kwiatkowski (ed.), Badania zachodniej części kwartału V. Archeologia Stargardu 1. Stargard, 149-158.

Majewski M. 2017. III.1. Wyroby ze szkła. In: M. Majewski, K. Stań (eds.), Badania na Rynku Staromiejskim. Archeologia Stargardu 3. Stargard, 103-107.

Markiewicz M. 1999. Posiedzenie Polskiego Komitetu Narodowego Association Internationale Pour l'Histoire du Verre. "Acta Universitatis Nicolai Copernici. Archeologia" 27. "Archeologia Szkła" 8, 180-181.

Meyza K. 2014. Wyniki archeologicznych badań sondażowych na wzgórzu widokowym w Ogrodzie Krasińskich w Warszawie. "Almanach Muzealny" 8, 15-43.

Morgan R. 1976. Sealed Bottles. Their History and Evolution (1630-1930). Burton-on-Trent. 
Mucha M. 1994. Archeologiczna weryfikacja nowożytnych hut szkła na terenie gminy Bierzwnik, w województwie gorzowskim. "Zeszyty Bierzwnickie" 1 (1992-1993), 59-82.

Mucha M. 1997. Dziewiętnastowieczne huty szkła w rejonie Bierzwnika i Dobiegniewa w świetle źródet archeologicznych. "Zeszyty Bierzwnickie" 2 (1994-1995), 107-126.

Nawracki M. 1999. Późnośredniowieczne i nowożytne szkła z terenu zamku krzyżackiego w Toruniu. "Acta Universitatis Nicolai Copernici. Archeologia" 27, "Archeologia Szkła" 8, 53-132.

Nowosielska K. 1998. Wyroby szklane. "Silesia Antiqua" 39, 247-261.

Olczak J. 1991. Nowe materiały do dziejów użytkowania szkła na ziemiach polskich (Część 1). "Acta Universitatis Nicolai Copernici. Archeologia" 19. "Archeologia Szkła" 5, 69-87.

Paduch R., Adamowicz R., Oczkoś L., Paduch R., Mum K., Sztandera M. 2009-2016. Mampe. In: Stare Butelki z Pomorza Zachodniego, http://www.butelki.porcelanki.net/readarticle.php?article_id=1.Available on-line: 07.10.2020.

Pawlata L. 2010. Badania archeologiczne przed fasada Pałacyku Gościnnego w Białymstoku, stanowisko 2 ul. Kilińskiego. "Biuletyn Konserwatorski Województwa Podlaskiego" 15/16, 59-81.

Piątkowska R., Żebrowski R. 2008-2020. Gwiazda Dawida. In: Polski Słownik Judaistyczny. Warszawa, http:// www.jhi.pl/psj/Gwiazda_Dawida. Available on-line 16.07.2020.

Polak A. 1981. Szkło i jego historia. Warszawa.

Poturalska E. 1999. Zabytki szklane z ratusza Nowego Miasta w Łowiczu. "Łódzkie Sprawozdania Archeologiczne" 5, 315-329.

Rais-Kufel E., Kufel R. 2013. Wyroby szklane. In: P. Pawlak (ed.), Średniowieczny system obronny miasta Poznania. Odcinek pótnocno-zachodni. Wyniki badań archeologicznych. Bibliotheca Fontes Archaeologici Posnanienses 15. Poznań, 237-278.

Rubnikowicz M. 1989a. XVIII-wieczna huta szkła w Średniej Hucie, gmina Warlubie, woj. bydgoskie. "Acta Universitatis Nicolai Copernici. Archeologia" 14. "Archeologia Szkła” 3, 39-66.

Rubnikowicz M. 1989b. XVIII-wieczne naczynia szklane odkryte na Starym Mieście w Toruniu. "Acta Universitatis Nicolai Copernici. Archeologia" 14. "Archeologia Szkła" 3, 73-84.

Rubnikowicz M. 1996. Średniowieczne i nowożytne szkło ze stanowiska Collegium Gostomianum. In: S. Tabaczyński (ed.), Sandomierz: badania 1969-1973 2. Warszawa, 423-453.

Ruszkowska U. 2007. Sprawozdanie z nadzorów archeologicznych przy kościele w Biskupicach, pow. świdnicki. “Archeologia Polski Środkowowschodniej” 9, 145-151.

Siemianowska S. 2015. Późnośredniowieczne i nowożytne szkło naczyniowe z badań wykopaliskowych na Ostrowie Tumskim we Wroctawiu prowadzonych w latach 1949-1961, 1963. "Silesia Antiqua" 50, 203-286.

Sieramska M. 2008-2020. Ryba. In: Polski Stownik Judaistyczny. Warszawa, http://www.jhi.pl/psj/ryba. Available on-line 16.07.2020.

Siwiak W. 2002. XVIII-wieczne butelki z ul. Pod Blankami 33 w Bydgoszczy. "Materiały do dziejów kultury i sztuki Bydgoszczy i regionu" 7, 22-32.

Siwiak W. 2003. Jeszcze o szklanych pieczęciach z Fordonu nad Wista. "Kwartalnik Historii Kultury Materialnej" 51(1), 59-62.

Siwiak W. 2004. Znaleziska szklanych pieczęci. "Materiały do dziejów kultury i sztuki Bydgoszczy i regionu" 9, $157-160$.

Siwiak W. 2007a. Szklane pieczęcie butelkowe znalezione w Labiszynie. Przyczynek do historii produkcji opakowań szklanych w środkowo-pótnocnej Polsce w XVIII-XIX wieku. In: Z. Zyglewski (ed.), Polska w kręgu polityki, kultury i gospodarki europejskiej. Księga pamiątkowa z okazji 70-lecia urodzin prof. Maksymiliana Grzegorza. Promotio historica bidgostiensia 2. Bydgoszcz, 200-210, https://bsmz.org/articles.php?article_id=38. Available on-line: 04.04.2019.

Siwiak W. 2007b. Nowożytne odciski szklanych pieczęci butelkowych ze zbiorów Muzeum im. Jana Kasprowicza w Inowrocławiu. "Materiały do dziejów kultury i sztuki Bydgoszczy i regionu" 12, 77-80.

Siwiak W. 2009. Nowożytne szkła z Przedmieścia Gdańskiego w Bydgoszczy. „Kronika Bydgoska” 30, 235-258, https://www.bsmz.org/articles.php?article_id=48. Available on-line: 04.04.2019.

Słomska J. 2013. Szkło. In: T. Poklewski-Koziełł (ed.), Centrum włości szlacheckiej w Pomorzanach i Pomorzankach pod Kutnem od 1375 do 1810 roku. Autostrada Al. Archeologiczne zeszyty autostradowe IAE PAN 14. Łódź, 141-143.

Starski M. 2015. Rynek miasta lokacyjnego w Pucku w świetle badań archeologicznych. Warszawa.

Stolpiak B., Świercz T. 1997. Badania archeologiczno-architektoniczne na terenie bytego opactwa cysterskiego w Bierzwniku w latach 1994-1995. "Zeszyty Bierzwnickie” 2 (1994-1995), 9-68. 
Stolpiak B., Świercz T. 1998. Badania archeologiczno-architektoniczne na terenie byłego opactwa cysterskiego w Bierzwniku w latach 1996-1997. "Zeszyty Bierzwnickie” 3 (1996-1997), 7-63.

Sulkowska-Tuszyńska K. 2018. Gniewkowo. Studia nad kultura przedmieścia (XIV/XV-XVIII w.). Stary Torun.

Szeremeta M. 2018. Wyniki badań archeologicznych przy ul. Ptatnerzy $1 F$ w Stargardzie. In: E. Trawicka (ed.), XX Sesja Pomorzoznawcza. Gdańsk, 387-396.

Szczepanowska K. 2013. Stemple szklane z badań archeologicznych Gdańska (stanowisko 100, Szafarnia - Angielska Grobla). "Gdańskie Studia Archeologiczne” 3, 283-300.

Szczepanowska K. 2015. Wyroby szklane. In: J. Dąbal, K. Krawczyk, T. Widerski (eds.), Gdańsk Twierdza Wistoujście. Badania archeologiczno-architektoniczne w latach 2013-2014 / Wistoujście Fortress, Gdańsk. Archaeological and architectural investigations, 2013-2014. Gdańsk, 299-324.

Szymczyk M. 2016. Badania archeologiczne w Myśliborzu w latach 1945-2014. "Materiały Zachodniopomorskie. Nowa seria" 12, 547-571.

Veit R., Huey P. R. 2014. „,New Bottles Made with My Crest”: Colonial Bottle Seals from Eastern North America, a Gazetteer and Interpretation. "Northeast Historical Archaeology" 43, 54-91, https://orb.binghamton.edu/ neha/vol43/iss1/4/. Available on-line 06.07.2020.

Wawrzyniak P. 2000. Kieliszki, szklanice, puchary... Rzecz o dawnych naczyniach szklanych, do wypitku stużacych. In: J. Wiesiołowski (ed.), ,, Na frasunek...”. Kronika Miasta Poznania 4. Poznań, 62-76.

Wiewióra M. 2000. Zespót klasztorny kanoników regularnych $w$ Trzemesznie $w$ świetle badań archeologicznoarchitektonicznych. Archaeologia Historica Polona 9. Torun.

Wilgocka A. 2016. Przedmioty szklane. In: M. Majewski (ed.), Archeologia Stargardu II (2). Badania na obszarze dawnego kościoła augustiańskiego. Stargard, 225-241.

Włodarczyk W. 2017. Winnice Warszawy i okolic w pierwszej polowie XIX wieku. Zarys problematyki badawczej. In: D. Dias-Lewandowska, G. Kurczewski (eds.), Fukier $i$ wino. Studia z historii wina 1. Warszawa, 136-225.

Wojciechowska I. 2015. Aqua fons vitae... - o nowożytnych pojemnikach do wody mineralnej ze zbiorów Muzeum Archeologiczno-Historycznego w Stargardzie. "Stargardia. Rocznik Muzeum Archeologiczno-Historycznego w Stargardzie poświęcony przeszłości i kulturze Pomorza oraz innych ziem bałtyckich" 9 (2014), 171-200.

Woźny J. 2001. Znaki na butelkach szklanych z XVIII-XIX wieku ze Starego Fordonu nad Wista. "Kwartalnik Historii Kultury Materialnej” 49(3), 245-252.

Żebrowski R. 2008-2020. Ariel. In: Polski Stownik Judaistyczny. Warszawa, http://www.jhi.pl/psj/Ariel. Available on-line 16.09.2020. 